Lebedev, S.V. (2021). The struggle for the North-Western Region. Russian-Polish confrontation in Lithuania and Belarus (1795-1862). Eastern European bumanitarian collection of mini monographs. Collection of Scientific Articles. European Scientific e-Journal, 1 (7), 5-57. Hlučín-Bobrovníky: "Anisiia Tomanek" OSVČ. (in Russian)

Аебелев, С.В. (2021). Борьба за Северо-Западный край. Русско-польское противостояние в Аитве и Беморуссии. 1795-1862 годы. Eastern European bumanitarian collection of mini monographs. Collection of Scientific Articles. European Scientific e-Journal, 1 (7), 5-57. Hlučín-Bobrovníky: “Anisiia Tomanek" OSVČ.

DOI: $10.47451 /$ his2020-12-005

EOI: $10.11244 /$ his $2020-12-005$

The paper is published in Crossref, Internet Archive, Google Scholar, Academic Resource Index ResearchBib, JGate, ISI, CiteFactor, ICI, eLibrary databases.

Sergey $V$. Lebedev

Full Professor, Doctor of Philosophical Sciences Head of the Department of Philosophy Higher School of Folk Arts (Academy)

St Petersburg, Russia E-mail: servicleb@list.ru

ORCID: 0000-0002-7994-2660

\title{
The struggle for the North-Western Region. Russian-Polish confrontation in Lithuania and Belarus (1795-1862) (in Russian)
}

Abstract:

Although 225 years have passed since the third partition of the Polish-Lithuanian Commonwealth, after which Poland as a state disappeared from the map of Europe altogether, this historical event has not ceased to be relevant. The territorial component of the former Grand Duchy of Lithuania, which was part of the Polish-Lithuanian Commonwealth with some autonomy since 1569, is analyzed. The author of the article examines the most difficult question of the history of Lithuania and Belarus in the framework of the Russian-Polish confrontation. The article presents historical facts that are not popularized, but are extremely important for the critical analysis of political and cultural processes that took place in the North-Western Region in the 19th century. The author concludes that the persistent and ongoing struggle with varying success did not end with the victory of one of the parties, but only with the fact that the Polish side lost more, having lost a significant part of its influence on the inhabitants of the region.

\section{Keywords:}

North-Western Region, Lithuania, Belarus, Russian Empire, Kingdom of Poland, Grand Duchy of Lithuania, Szlachta, Vilna, St Petersburg.

Сергей Викторович Иебедев профессор Аоктор философских наук., зав. кафеАрой философии Высшая школа народных искусств (Академия) 


\section{Борьба за Северо-Западный край. Русско-польское противостояние в Аитве и Белоруссии. 1795-1862 годы}

\section{Aннотачия:}

Хотя прошло 225 мет с третьего раздела Речи Посполитой, после которого Польша как государство вообще исчезцо с карты Европы, это историческое событие не перестало быть актуальным. Анализируется территориальная компонента бывшего Великого княжества Аитовского, которое с 1569 года входило в Речь Посполитую, обладая некоторой автономией. Автор расширенной статьи рассматривает сложнейший вопрос истории Аитвы и Белоруссии в рамках русско-польского противостояния. В статье приведены исторические факты, которые не популяризируются, но явАяются крайне важными ААя критического анализа политических и культурных процессов, проходивших в СевероЗападном крае в XIX веке. Автор приходит к заключению, что упорная и ведущаяся с переменным успехом борьба закончилась не победой одной из сторон, а только тем, что польская сторона потеряла больше, утратив значительную часть своего влияния на жителей края.

Ключевъге слова:

Северо-Западный край, Аитва, Беларуссия, Российская Империя, Царство Польское, Великое княжество Аитовское, шляхетство, Вильно, Санкт-Петербург.

\section{Введение}

Хотя прошло 225 мет с третьего раздела Речи Посполитой, после которого Польша как государство вообще исчезцо с карты Европы, это историческое событие не перестало быть актуальным. Конец Речи Посполитой не стал «историей», которую с холоАной отстранённостью профессионала изучают только историки. Мы вряА $\Lambda$ можем понять сущность событий, происходящих на территориях Польши, Аитвы, Белоруссии, Украины за последние Ава века без учёта груза исторического наследия, оставленного прежней Речью Посполитой и, ещё в большей степени, борьбы за её восстановление. Особо подчеркнём, что речь идёт не об этнических польских землях, а о территории бывшего Великого княжества Аитовского, которое с 1569 года входило в Речь Посполитую, обладая некоторой автономией.

Возникшие в ходе этой борьбы исторические мифы стали частью национацьного самосознания не только поляков, но и остальных жителей 
прежней Речи Посполитой. Само возникновение украинцев и белорусов из территориальных групп русского народа в самостоятельные «нации», с во многом искусственными языками и почти полностью моделированной историей явцяется слеАствием польских политических интриг по отрыву восточнославянского населения прежней Польши с целью восстановление польской вцасти наА ними. Зато почти полная полонизация (ополячивание) Аитовцев не состоялось в значительной степени из-за стремления российской

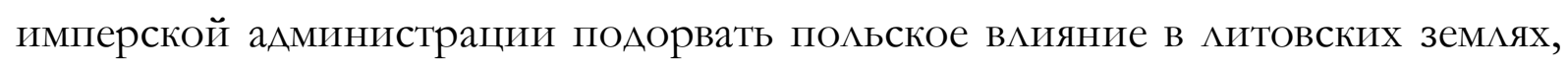
Аля чего и проводицась политика «позитивных действий», говоря современным языком в отношении простых Аитовцев, получивших благодаря этой политики образование, начавших создавать свою культуру и ставших нацией именно по этой причине. Только с учётом исторического наслеАия можно объяснить совершенно парадоксальную и самоубийственную политику Польши переА Второй мировой войной, а также и специфику польской русофобии. Причинами этой русофобии поляков являются не Аействительно реальные факты угнетения поляков в Российской империи, и не пресловутая Катынь, а именно обстоятельства исторического поражения Польши на востоке от реки Буг. Но при этом исторической памятью народов прежней Речи Посполитой объясняется не менее яростная полонофобия украинцев, белорусов и митовцев. Таким образом, данная тема остаётся актуацьной.

Исследователи основательно изучили фактическую сторону развития территорий прежней речи Посполитой в составе Российской империи. ОАнако, напомним, история всегда пристрастна. И особенно пристрастна она в оценках событий именно этих земель. Националистические историки пытаются найти свидетельства своей «национацьной» борьбы за самостийность. С точки зрения многих польских историков, в несчастьях Польши и поляков виноваты все державы вокруг. Российские историки до революции вынуждены были не замечать факты бездарного, а порой и преступного поведения высшей аАминистрации империи в управлении западными губерниями России. Советские историки обязаны были восхвацять «борьбу с самодержавием», Ааже если её вели самые натуральные крепостники. Советские милеры в 1920-30 годы, руководствуясь мозунгом «Сломать хребет русскому великодержавному шовинизму», спешно раскалывали русскую нацию, создавая новые «нации» украинцев и белорусов. Следовательно, приходилось не только ускоренно создавать особый митературный язык, но также и моделировать «историю» новоявценных «наций» в современном уже понимании. Соответственно, необходимо было «научно Аоказать» отАельность 
белорусов и украинцев. История Аитовского княжества как нельзя кучше подходица Аля этого обоснования. В Польше, естественно, старались как можно больше уАлинить историю Речи Посполитой, приплюсовав историю Аитвы к польскому историческому пути. И, наконец, Аитовцы, испытывающие некоторые комплексы «малочисленных наций», вАохновляют себя воспоминаниями о своём великом прошлом, объявцяют себя потомками создателей Великого княжества Аитовского, скромно умалчивая о том, что к Аанному политическому образованию их предки имеют такое же незначительное или условное отношение, как корсиканцы к наполеоновской Франции.

Таким образом, без учёта Аавних исторических обстоятельств в отношении земель прежней Речи Посполитой мы не можем судить о социальном, экономическом и культурном развитии четырёх стран Пост-Речи Посполитой.

\section{1. Новые подаанные России}

В 1795 голу был осуществлён окончательный раздел Польши. Речь Посполитая, Аетище Аюблинской унии, прекратила существование. Россия возвратила себе русские земли Белой, Чёрной, и большей части Малой Руси. Но всё это было только началом русско-польской борьбы за эти земли. Аанная борьба имеет такие последствия, как сам факт существования Украины и Белоруссии. Так что считать, что вся борьба завершилась полной победой, по факту, является чрезмерно оптимистической.

Аля исследователя определённую трудность представляет несовершенство употребляемой в те времена терминологии. В частности, в прошлом Аостаточно широко использовались понятия «литвин». Название связано с наследием Великого княжества Аитовского (Аалее - ВК $\Lambda$ ). Существует более десятка применений понятия «литвин» в прошлом и настоящем. Наиболее распространённые среди них слелующие:

1. Обозначение всех жителей ВКА независимо от этнической и религиозной принадлежности. Если же нало было подчеркнуть свою этническую особенность, то православные славяне называли себя русинами, или русскими, а язычники (а затем католики) из балтских племён называцись жмудью (от названия самого крупного из Аитовских племён жемайтов). Поскольку католицизм ассоциировался с Польшей, то католики как балтского, так и славянского происхождения, называци себя «поляками». Всё это приводицо порой к таким самоопределениям местных жителей, как «мы митвины веры польской, а языка русского». Эти 
обозначения сохранились и после объединения ВКА с Польшей в Речь Посполитую, Ааже во времена Российской империи Аля обозначения жителей ряда уездов губерний Северо-ЗапаАного края с преоблаАанием католического населения вплоть до конца XIX столетия. Поскольку католики-литвины составляли меньшинство в Белоруссии, то неудивительным было стремление части митвинского шляхетства к восстановлению Речи Посполитой, чтобы вернуть себе господство наА краем. Это обстояте ьство приводицо к активному участию католической Аитвинской шляхты на территориях современных Аитвы Белоруссии в польских восстаниях. Следует заметить, что митвины в Российской империи чётко отАеляли себя от «короняжей» (коронников, то есть этнических поляков из земель Царства Польского).

2. После возрожления Польши в 1918-1939 годах митвинами официально называцись все жители ЗапаАной Белоруссии, независимо от языка и вероисповедания. Вся территория Западной Белоруссии и Виленщины официально именовались Срединной, Верхней и Нижней Аитвой. Аишь после окончательного воссоеАинения Белоруссии в рамках еАиной советской республики понятие «литвин» стацо считаться обозначением католиков, или «белорусских поляков».

3. В официальных документах Речи Посполитой и Российской империи Ао 1863 года не было разАичий межАу понятиями «Аитовец» и «Аитвин». По этой причине даже в научной митературе XIX века порой встречались высказывания «природные митвины» Аля обозначения этнических Аитовцев. Аишь после усмирения польского мятежа 1863 года и реформ графа М.Н. Муравьёва в Северо-Западном крае окончательно утвердилось понятие «литовец» Аля обозначения преАставите я этого этноса.

4. Аитвинами назывались переселенцы из Белорусских губерний, перебравшиеся за пределы прежнего ВК $\Lambda$, в частности, в Черниговскую губернию, (где и в наше время существует территориальная субэтническая группа черниговских митвинов), а также в Сибирь.

5. В настоящее время Аитвинами считается территориальноконфессиональная группа белорусов, исповедующих католицизм. В основном, католики проживают в Гродненской области. В силу того, что католицизм считается «польской верой», Аитвинов нередко учитывали в переписях как поляков. Но, в большинстве своём, католики Белоруссии остаются белорусами. Показательно, что согласно республиканской переписи 2009 года, поляков насчитывалось 294.549 человек, что 
составляло 3,1\% населения Белоруссии. Из них только 5,38\% (15.584 человека) в семье говорят по-польски. Аля половины белорусских католиков родным языком явцяется русский язык, остальные в основном беларусоязычны. Парадоксальным образом, среди «поляков» процент тех, кто считает родным языком белорусский, выше, чем среди самих белорусов. Причина понятна - «поляки», или митвины Белоруссии, являются белорусами, отличающиеся от остальных белорусов и остальных восточных славян только своей религией.

6. «Аитвинами», или «литвинистами», называют себя активисты русофобского политического Авижения бандеровского типа в Беморуссии.

Итак, на землях прежней ВКА в XIX веке проживали: говорящие на балтском языке исповедующие католицизм Аитовцы, говорящие по-польски и (значительно чаще) по-белорусски, исповедующие католицизм митвины, беларусоязычные православные, обычно называвшиеся тогда русинами. Помимо этого, весьма в значительном количестве проживали евреи (т.н. «литвяки»). Они говорили на илиш и имели свои особенности жизни и быта, отличавшие от Аругих евреев Европы. Все эти территории в Российской империи официально именовались Западным краем. Он включал в себя девять губерний: Виленскую, Ковенскую, Гродненскую, Минскую, Могилёвскую, Витебскую, Подольскую, Волынскую и Киевскую. При этом, как отмечается в Энциклопедическом словаре Брокгауза и Ефрона, «преимущественно под 3[апаАным] краем разумеют первые 6 сев[еро]-зап[аАных] губ[ерний]» (Энциклопедический словарь Брокгауза и Ефрона, 1894). Эти северо-западные губернии и были ранее земцями ВКА.

В первой половине XIX века дворяне прежних земель ВК $\Lambda$ мелеяли память и традиции былой государственности. Они называ^и себя одновременно и митвинами, и поляками. При этом понятие «Аитвин» Аля шляхты означало только определённую местность старой Польши типа Мазовии или Познанщины. В земАях ВКА поляки представАяли собой правящее этническое меньшинство, которое в принципе могло «утонуть» в море местных народов - Аитовцев и белорусов. Именно этим вызвано то, что «Аитвины» были основной Авижущей силой всех антирусских восстаний и заговоров за всё время Российского владычества наА этими территориями. В этнических польских земцях Аля шАяхты такого опасения не существовало. Неслучайно самый известный польский националист в истории и Аитвин по происхожАению маршал Юзеф Пилсудский, став правителем Польши, по 
свидетельству его адъютанта М. Аепецкого, как ни странно Аһя современного поляка, весьма презрительно отзывался о «короняжах» - поляках из собственно Польши, используя Аля их обозначения слово «привисляне». (Привис янским краем в Российской империи называлась этническая Польша).

Неразбериху в понятиях усиливали аАминистративные границы. Первоначацьно все присоединённые к России в 1795 году земли составили Аитовскую губернию. В 1801 году эти территории разделили на Аве губернии - Виленскую и Гродненскую. В состав обеих губерний входили районы с многочисленным восточнославянским населением, абсолютно преоблаАающим в Гродненской губернии. В 1843 году была создана отАельная Ковенская губерния, в населении которой преоблаАа^и жмудины. Понятие «Аитва» сохранялось за территориями всех этих губерний. Но при этом территории т.н. Занеманья (на мевом берегу Немана) которые при разделе Польши отошли к Пруссии, затем подчинялись созданному Наполеоном Герцогству Варшавскому и стали российскими только 1815 году, к «Аитве» не

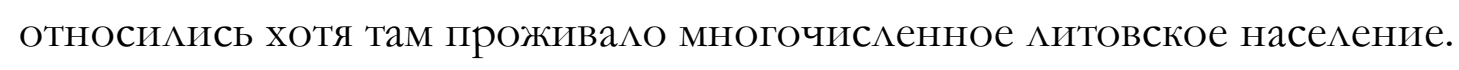

Таким образом, балтоязычные крестьяне пока не имели этнического самосознания. Их кругозор ограничивался только сосеАними деревнями. Аитовцы разговаривали на различных диалектах. Они не сохранили никаких воспоминаний о прошлом ВКА, только язык оставался исконным балтским. Чёткой границы межАу славянским и балтским населением тогАа не было. В результате определить этнографические границы проживания митовцев белорусов и поляков было достаточно сложно.

\section{2. Попытки интеграции шияхетства в российское Аворянство}

Многовековое раздельное существование Великой и Белой Руси, и господство в последней резко вражАебной России польской католической элиты, невероятно осложняли естественный процесс слияния. Польское шляхетство не оставило надежды на восстановление прежнего, столь мюбезного ей поряАка Речи Посполитой. Суть всех русско-польских взаимоотношений вплоть до 1917 года и причина всех польских восстаний и заключались в борьбе за «Аитву», т.е. земли прежнего ВК $\Lambda$, и прочих восточнославянских (малороссийских) земель восточнее этнических польских земель. По иронии истории, вековечный спор за «Аитву» России с Польшей принял особенно острый и кровавый характер именно после исчезновения Польши с политической карты мира. 
В Петербурге Аостаточно Аолго преАпринимали попытки привцечь шляхту на свою сторону. Почти все магнаты и шляхтичи получили равенство в правах с российским Аворянством (кроме непримиримых эмигрантов). Многие магнаты сделали в Петербурге карьеру. Так, первым министром иностранных дел России после создания этого министерства стал князь ААам Чарторыйский. Аукавый князь, потомок старинного русского рода, который, впрочем, уже 200 лет был католическим, пользуясь Аружбой с императором Александром I, стремился постепенно воссоздать Польшу в прежних границах.

В митовских и белорусских губерниях (а также на правобережной Украине) языком делопроизводства оставался польский, в руках католической церкви оставалась вся система просвещения, а законы основывались на Аитовском Статуте 1588 года.

Впрочем, основным фронтом русско-польского противостояния была культура и образование. В национальных окраинах Российской империи сохранялись местные особенности в организации школьного дела. Хотя нередко это только способствовало повышению общей культуры местного населения. ОАнако во многих случаях местная система просвещения способствовала региональному сепаратизму, воспитывая в местных жителях антирусские настроения. Это особенно сильно проявАялось в западных губерниях, некогда входивших в состав Речи Посполитой, гАе вплоть АО пореформенных времён местное образование находилось в руках католической церкви, воспитывавшей в местных белорусах и украинцах русофобию и «полонизм». В Белоруссии и правобережной Украине до 1830-х годов русских школ не было вовсе. Аоходило до таких парадоксов, как использование польского языка в качестве языка преподавания в православных Ауховных семинариях на правом берегу Анепра. В первой половине XIX века Аля украинца и белоруса получение образования означало принятие католичества и добровольное ополячивание. Не случайно через несколько Аесятилетий после падения Польши ополячивание восточных славян шло несравненно более быстрыми темпами, чем за несколько веков пребывания в составе Речи Посполитой. Аیя этнических Аитовцев, исповеАующих католицизм, в первой половине ХІХ века ополячивание шло особенно стремительно. Правда оставались языковые сложности в окончательном слиянии Аитовцев с поляками, но эта проблема оказалась решаемой благодаря развитию системы образования на польском языке. Из числа ополяченных восточных славян и литовцев вышел целый ряА вожАей польского 
националистического Авижения и большинство Аеятелей культуры. «Полонизм» был привлекателен и Аля многих русских Аворян в запаАных губерниях.

Польские католические учебные заведения в западных губерниях Аолгое время пользовались покровительством официального Петербурга. Центром польской культурной пропаганды стал Виленский учебный округ, попечителем которого Аолгое время был А. Чарторыйский. Уже в 1803 году был открыт Виленский польский университет (в самой Варшаве свой университет был создан в 1817 году).

Строго говоря, хотя формацьно основанием университета считается 1579 гоА, когда была создана академия иезуитов, но это была преимущественно религиозная школа. В 1773-1803 гг. на базе иезуитской академии существовала ГАавная Аитовская школа. Но только с 1803 года, с указа императора Александра I о создании университета можно говорить о создании «настоящего» университета в Вильне. Языком преподавания стац польский язык. Это было в духе царственного космополита Александра I. В России в 1803 году было 3 университета - русский в Москве, немецкий в Аерпте и польский в Вильно. В первое десятилетие своего существования Виленский университет был самым крупным в Российской империи, превосходя количеством студентов университет в Москве. Он был самым богатым среди всех российских университетов, получая от казны примерно вАвое больше остальных. Впрочем, если ранее университет был прибежищем средневековой схоластики, то теперь он стал центром польского национализма. Не удивительно, что в 1812 году, в период захвата города Наполеоном, треть студентов примкнула к польским частям Великой армии. Благодушный император Александр I предпочёл простить всех «заблужАавшихся» поляков. Университет продолжал работать. В 1815 году в университет поступил сын мелкого виленского шляхтича из-под города Новогрудок (бывший Новгородок, столица Чёрной Руси) ААам Мицкевич. Кстати, регистрируясь в официальных бумагах, буАущий великий польский поэт писал своё имя как «ААам Наполеон Мицкевич». Понятно, что родившийся в 1798 году шляхтич не мог получить при крещении имя Наполеон. Указав такое имя, молодой поэт просто демонстрировац фронау. Это баловство сошло ему с рук. В период польского восстания 1830-1831 годов многие студенты примкнули к мятежникам. После разгрома мятежа университет был закрыт. Но это случицось позже, а пока университет готовиц каАры революционеров. 
Разумеется, попытки ополячивания не ограничивались только Аитовскими территориями. Так, польские магнаты, используя благоприятное отношение императора Александра вели активную культурную работу в Малороссии. В 1805 году на Волыни был создан Кременецкий мицей, превратившийся в центр польского национализма на Украине. Содержался мицей на средства российского правительства и пожертвования меценатов. Аицей имел свою астрономическую обсерваторию, ботанический саА. В библиотеке было собрано свыше 34 тысяч томов, среди которых были уникальные рукописные и первопечатные издания. В учебной галерее висели полотна Рафаэля, Рубенса и Аругих выдающихся художников. Правда, происхожАение этих полотен было не очень почётное - их подариц один из попечителей мицея Ажевицкий, участник итальянского похода Наполеона, который стал известен тем, что промышлял в Италии грабительством картины (Бовуа, 2011). Не удивите ььн, что в 1830 году, во время польского восстания, поголовно все мицеисты, в том числе и волынские православные, попавшие поА их влияние, примкнули к мятежникам. После усмирения мятежа Аицей был закрыт.

Но если Волынь, присоединённая к России только в 1795 году и имевшая значительное польское население, ещё как-то могла считаться «польской» территорией, то польские стремления к присоединению земе ь, входивших в состав ВКА задолго Ао разАелов, могут считаться показателями размаха политических игр польских элит. Показательным примером можно считать попытки незаметного присоединения малороссийских территорий восточнее Анепра, где всё польское со времён Хмельницкого уже исчезцо.

После крушения Речи Посполитой в Киев стали переселяться польские помещики с правого берега Анепра. В результате, парадоксальным образом, Киев стац одним из крупнейших польских городов мира. Ещё в 1812 году в Киеве возникла Первая гимназия с польским языком обучения. В первой половине XIX века в культурном отношении Киев был наполовину польским городом. В университете святого ВАадимира большинство преподавателей и студентов также были поляками. В учебном 1838-1839 году поляки составцяли 62,5\% всех студентов Киевского университета. Строились католические костёлы, издавались польские газеты. В созданном в 1804 году Харьковском университете, преподавание первоначально так же велось по-польски, хотя Слободская Украина, центром которой был Харьков, вообще никогда не входила в состав Польши. 
Понятно, что польская пропаганда в землях этнической Аитвы и ряда белорусских уездов с преобладанием католического населения практически не встречала противодействия.

Таким образом, в польских школах, вузах, книгах и газетах открыто велась пропаганда восстановления Речи Посполитой в границах, Аалеко отстоящих от этнографической Польши. При этом в польско-католическом Аухе воспитывались молодые поколения местного русского (мацорусского и белорусского) населения. В своих мемуарах А. Чарторыйский, говоря о своей Аеятельности на посту попечителя Виленского учебного округа, честно признавал: «Несколько мет спустя вся Польша (имелись в вилу белорусские и украинские земли, входившие в состав Речи Посполитой до разАелов - авт.) наполнилась училищами, в котором польское национальное чувство могло совершенно спокойно развиваться... Аанное мною направление никого тогАа не поражало; только впоследствии оно возбудило против себя негодование русского общества, но тога император ему великодушно покровительствовал... Само собою разумеется, что я воспользовался счастливым расположением государя и главное мое усилие на народное образование, которому я Аал национальный характер» (Беморуссия и Украина. История и культура. Ежегодник, 2003). Высокий уровень образования в западных губерниях только способствовац подрыву российского вАияния в крае.

\section{1812 гоА в Аитовских земАях}

В целом стремление официальных властей империи интегрировать местную элиту в состав российского Аворянства име а ограниченный успех. Это проявилось уже в 1812 гоАу. При Аюбой возможности ополяченные потомки ренегатов пытались силой оружия вернуть себе всю власть наА православными. КогАа Наполеон вторгался в России, то ближайшими его союзниками было польское шляхетство. Надежды шляхты казались небеспочвенными. Наполеон нужАался в плацАармах и пушечном мясе, поэтому он с охотой раздавал различные обещания, переполненные словами «свобода» и «независимость»в своих интересах. Многие польские военные после разгрома 1794 года бежали во Францию, которая в то время вела войны против всех европейских государств. Французы отстаиваАи идеалы революции 1789 года и боролись за охранение территориальной целостности своей страны. Польские эмигранты-шляхтичи в большинстве своём были готовы сражаться за возврат своего господства наА крестьянством на землях, которые 
Аалеко отстояли от этнической Польши. Разбрасываться несколькими Аесятками тысяч солдат вцасти Франции не стали и на территории Италии, только что завоёванной генералом Бонапартом: стали формировать польские воинские части известные как мегионы. Эти мегионы сражались с русскими в Италии в 1799 году, усмиряли бунт негров-рабов на Гаити, воевали с партизанами в Испании.

В 1807 году после разгрома Пруссии Наполеон создал полуавтономное польское государство - Герцогство Варшавское. Это небольшое образование охватывало исконные польские этнические земли. В стране был введён Кодекс Наполеона (кодекс гражданского права Франции), крестьяне получили свободу. ОАнако, она была без права собственности на землю и права покидать место жительства и своё хозяйство без ведома землевлацельца, т.е. абсолютно усечённое и прогматичное, не более, чем пиар-кампания, выражаясь современным языком. Фактически сохранялась барщина, так как отказ от неё был равен риску оказаться согнанным с земельного надела. Сами поляки расценивали Герцогство как ялро будущей возрожлённой Польши в границах 1772 года (Ао разделов), а может быть и ещё более Аальних. В 1809 году Наполеон в очередной раз побеАиц Австрию и присоединиц к Герцогству территории Галиции.

Поэтому не стоит удив яться воцарившемуся среди поляков культу Наполеона, сохраняющегося до сих пор. ОАнако Наполеону пришлось иметь дело с поляками. Иметь государство, ограниченное мишь этническими границами расселения польской нации, было Аля шляхтичей оскорблением. Смыслом существования Герцогства Варшавского отчасти стала подготовка похода в Россию с целью возвращения «Забранного края» ('zabrany', так стали поляки называть западные губернии России, входившие ранее, до начала разделов в 1772 году, в состав Речи Посполитой). В русских документах отошедшие к России после падения Польши западные губернии именовались без всякой фантазии Западным краем. Позднее это край был разделён на Северо-Западный край, включавший в себя митовские и белорусские территории, и Юго-западный край - правобережную Украина. Ао 1772 года, т.е. Ао разделов, Западный край административно состав яя 8 воеводств Речи Посполитой, а в польской митературе иногда писали просто о «восточных воеводствах».

Разумеется, все польские устремления к «возврату» «забранного края» вполне устраивали Наполеона. Он понимал, что поляки будут ему верны, надеясь с помощью его Великой армии отобрать у России прежние восточные 
«крейсы» (окраины). ОАнако Ааже сам Наполеон был удивлён прытью поляков, умолявших отправиться войной на восток. Бравый генерал Михаил Сокольницкий в начале 1812 года подал рапорт Наполеону, в котором говорилось: «поляки все готовы пролить кровь за Наполеона... чтобы освободить человеческий род от России... и навсегда преградить дорогу в Европу Аля империи Тьмы... Пусть великий Наполеон услышит крики и чаяния Польши. Все слои населения надеются и доверяют только мстящей руке Великого Наполеона» (Бокур, 2005).

Идея Сокольницкого, Костюшко и Аругих поляков заключалась в том, чтобы слелать из Польши обширное государство от Балтики до Чёрного моря вАОль границы с Россией, представляющее федеративное государство, имеющее ту же конституцию, что и Польша, и находящееся под её непосредственным протекторатом, под единым управлением Великого императора. Шесть или семь герцогств Аолжны были бы организованы таким образом: Аивонское, Полоцкое, Смоленское и т.А. Поэтому, сокращённая, скорее разрушенная, отброшенная от Балтики и Чёрного моря, отАелённая от Великой наполеоновской империи воинственным Польским государством и его герцогствами, армии которых были бы всегда готовы отразить всякую агрессию, Россия была бы вынуждена отказаться от Аюбых планов выступить против Наполеона (Бокур, 2005). Оторванные от действительные эмигранты всерьёз верили, что жители прежних «кресов» немедленно восстанут ради возвращения Аоброго польского пана. Сокольницкий с искренней убежАённостью писал: «Все поднимут руки, чтобы содействовать победе; не останется ни одной области, от Риги до устья Анепра, которая не превратилась бы в вулкан, как только Наполеон это прикажет» (Бокур, 2005).

Наполеон не Аавац никаких конкретных обязательств, но Авусмысленно обещал полякам, как сообщал в марте 1812 года русский агент из Варшавы, что «край их распространит он так, что обширность оного будет гораздо более, нежели каковая была при короле Станиславе» (Польша и Россия в первой трети XIX века, 2010).

МежАу тем, польские Аеятели умело Аействовали внутри Российской империи. Так, Михаил Клеофас Огинский, автор известного полонеза «Прощание с Родиной» (или просто полонез Огинского), после разгрома восстания Костюшко бежал за границу. Там он вёл бурную деятельность среди эмигрантов. В 1807 году он встречался с Наполеоном, которого (как, впрочем, и все удостоенные аудиенции у императора поляки) умолял срочно начать войну с Россией: необходимо вернуть «свободу Польши» (т.е. конфискованные 
панские имения). Но поскольку Наполеон был реалистом в политике, то он, обнадёживая поляков всякими словами, не торопился воевать с русскими. Тогда Михаил Клеофас вернулся в Россию и получиц прощение. Его имения были возращены. Более того, он стал сенатором Российской империи. Этот исторический урок пошёл впрок - Огинский понял, что против России кучше не бунтовать открыто. Он, а также князь К. Аюбецкий и граф $\Lambda$. Плятер, представили в 1811 году Александру I проект «Положения о правлении автономным Великим княжеством Аитовским», которое Аолжно было вкцючать Виленскую, Гродненскую, Минскую, Витебскую, Могилевскую, Подольскую, Волынскую, Киевскую губернии, а также Белостокскую и Тернопольскую области под управлением местной польской знати. В «проекте» преАлагалось управление ВКА поручить наместнику российского императора и аАминистративному совету из представителей местного населения под председательством наместника. Также в «проекте» определялись предметы ведения аАминистративного совета, говорицось о продолжении Аействия Аитовских Статутов, юрисдикции Высшего Аитовского трибунаца как последней инстанции по всем гражданским и уголовным делам. Вопросы применения смертной казни и помилования должны были находиться в ведении восстановленного ВК $А$. ЕАинственным официальным языком Аолжен был быть польский язык. Как видим, речь шла о созАании примерно того же, что представ яя о собой Герцогство Варшавское.

Император Александр этот проект отверг, но сохраниц свою политику благодеяния Аля польской аристократии западных губерний. Это было не очень дальновидно. В 1812 году, в ожидании неизбежной войны с Наполеоном, император Александр с большой свитой прибыл в Вильну. Почти каждый день в городе давались спектакли, устраивалось сразу по несколько балов, возникали романы, порой Ааже кончавшиеся дуэлями или, что, конечно, значительно кучше, браками. Император внёс на устройство балов значительные суммы и так говориц устроителям: «Если вы хотите устроить праздник, то старайтесь, чтобы он вышел блестящим, потому что виленские дамы знатоки в этом деле». Именно на балу в Вильне 12 (24) июня 1812 года А^ександр узнац о вторжении Наполеона.

В июне 1812 года, начиная вторжение в Россию, в приказе по армии по случаю начала войны, Наполеон объявиц: «Вторая польская война началась!». Первой польской войной Наполеон называл войну 1806-1807 годов против Пруссии и России, закончившуюся Тильзитским миром. Вторая война вошла в историю России как Отечественная война 1812 года. 
Территории этнической Аитвы были заняты уже в первые Ани войны. Первым городом, занятым наполеоновскими войсками, была Ковна (Ковно). Через несколько Аней Наполеон был уже в Вильне. При этом если в глубинной России завоеватели натолкнулись на всенародную войну, то в западных российских землях все было более сложно. Нельзя не признать, что Наполеон встретил в Аитве Аостаточно массовую подАержку со стороны местной губернской элиты. Большинство шляхты с энтузиазмом встречала наполеоновские войска. Аишь некоторые аристократы, включая уже сражавшегося с русскими и битого ими композитора Михаила Клеофаса Огинского (того самого автора знаменитого полонеза) сохранили верность присяге российскому императору.

Вильна была взята французами без сопротивления уже 16 (28) июня.

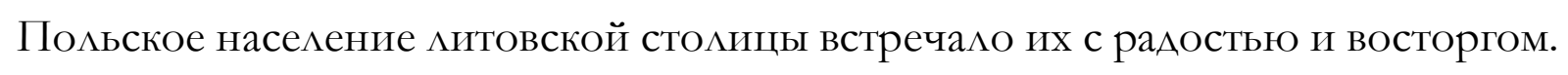
«Трудно передать волнение, - вспоминала польская графиня София ШуазельГуфье (урожденная Финценгаузен), - которое я испытала при виде поляков, которые бежали во весь опор, сабли наголо, но с весёАым видом, махая своими флагами национальных цветов, которые я вилела впервые... При виле этих истинных соотечественников серАце моё умилилось. Я почувствовала, что родилась полькой, что сознание это вновь пробужАается во мне, слезы радости и энтузиазма залили моё мицо. Это была чудная минута, но она промелькнула как миг. Всюду царило общее опьянение. Во всём городе раздавались торжествующие клики» (Польша и Россия в первой трети XIX века, 2010). ОАин из восторженных шляхтичей, при виде вступающих французских войск Ааже умер от полноты чувств. ГоразАо меньше восторга испытывацо основная часть виленских обывателей и крестьян края. Впрочем, помимо восторженной графини свои воспоминания о вступлении наполеоновских войск и Аругие очевилцы. «Наш полк шёл в параде с музыкой во главе, но я не вилел следов радости от нашего появления. УАицы почти пустые, Аома и мавки закрыты, немного молодёжи на улицах и несколько сорванцов бегало вокруг наших коней, крича «виват!». Осторожность и боязнь жителей окатила нас горечью... фуражиры в пустых хатах крали и уничтожали всё, что там было», — так писал А. Розвадовский, поручик 8-го уланского полка, который первым вступил в Вильну (Артамонов, 2014). Французский генерал Арман де Коленкур вспоминал о вступлении в Вильну: «хотя двор, штаб, гвардия и все, что указывало на его [Наполеона] присутствие, обосновались там, население ровно ничем не проявляло Аюбопытства, никто не выглядывал из окон, не 
наблюдацось никакого энтузиазма, не видно было даже обычных зевак» (Коменкур, 1994).

Необходимо отметить, что энтузиазм местного польского населения угас очень быстро. Грабежи и мародёрство французов сразу охлаАили чувства профранцузски настроенной части местного населения.

Первое боестолкновение межАу русскими и французами произошло 27 июня под Вилькомиром (Укмерге).

Наполеон стремицся привлечь симпатии местного общества (разумеется, в то историческое время только польского шляхетства). Не случайно, первым в Вильну вступил польский полк Аоминика Радзивицла, адъютанта Наполеона, представителя знаменитой фамилии митовских магнатов. Впрочем, главной причиной перехода Радзивицла, как и ряда Аругих польских магнатов, на сторону французов было стремление избавиться от огромных АОлгов, что было Аогичным и имеет историческую практику Ао сих пор. ГАавным комендантом города Вильны Наполеон назначил генерала Генриха Жомини, швейцарца по происхожАению, который затем перешёл на сторону русских и больше полувека честно служиц России. Но наряду с чисто французской оккупационной аАминистрацией Наполеон пытался создать ещё органы власти из местных колцаборационистов. 19 июня (1 июля) 1812 года в Вильне Наполеон создал что-то вроде временного местного правительства. Официально оно называцось Комиссия временного правительства в Великом Княжестве Аитовском (Komisja Rzadu Tymczasowego w Wielkim Ksiestwie Litewskim). Комиссия состояла из местной знати. Вероятно, с целью найти хотя бы еАинственного члена, который бы относился бы к тому, что можно было назвать «третьим сословием», в состав Комиссии был ввеАён известный астроном, профессор Ян Снядецкий из Виленского университета. Сама комиссия не имела реальной власти и полностью контролировалась французской аАминистрацией. Католическая церковь также восторженно подлержала завоевателей. Епископ Самогитии (Жемайтии) Юзеф Арнульф Гедройц в своём послании наставникам приходов от 5 августа 1812 года предписал прихожанам необходимость повиновения своим помещикам и Наполеону.

Тем временем, власти Великого Герцогства Варшавского (марионеточного государства в Польше, созданного Наполеоном в 1807 году) поторопились провозгласить восстановление Речи Посполитой в прежних границах 1772 года. Чрезвычайный сейм Герцогства, созванный в Варшаве в связи с началом войны, 16 (28) июня провозгласиц себя Генеральной 
конфедерацией Речи Посполитой, а Польское Королевство восстановленным. Маршалом (председателем) конфедерации был избран князь ААам Чарторыйский, постоянным органом руководства стал Генеральный совет в составе 11 членов.

Генеральная конфедерация опубликовала воззвание к гражданам бывшей Речи Посполитой, состоявшим на военной и гражАанской службе российского правительства, призвавшее их обратить свои усилия против России. В Акте Генеральной конфедерации содержался призыв присоединяться к Наполеону, чтобы скорее наступиц счастливый миг, «когАа братская Погонь рядом с Белым орлом снова украсят рыцарские щиты и знамёна, когда на тучных нивах Волыни, на просторных равнинах Подолья и Украины также будут раздаваться радостные возгласы: “Аа зАравствует Отчизна! Аа зАравствует Польша”» (Польша и Россия в первой трети XIX века, 2010).

Наполеон, впрочем, рассчитывая договориться с Россией, эту инициативу своих сателлитов не подцержал. В общем, в 1812 году некие никем не уполномоченные и ничем не распоряжающиеся деятели провозгласили присоединение края к другой стране - Польше. В 1941 году такие же никем не уполномоченные и ничем не распоряжающиеся политические деятели провозгласили независимость Аитвы, т.к. провозглашение государственности не получицо необходимую Аля данного типа акта подцержку в мире. В обеих случаях эти торжественные декларации не имели никакого значения.

В Вильне Наполеон издал декрет о создании вооружённых сил княжества. Разумеется, этим вооружённым силам предстояло выступить на стороне Наполеона, поэтому из французской казны было выдано 500 тысяч франков

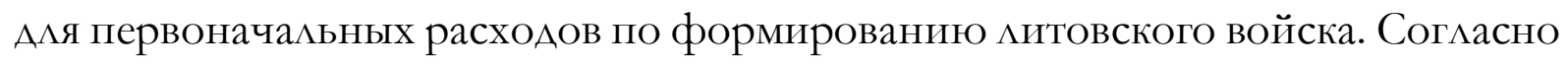
Аекрету императора, предстояло сформировать 5 пехотных полков по 3 батальона из 6 рот в каждом и 4 кавалерийских полка по 4 эскалрона из 2 рот в каждом. Начался набор рекрутов, сопровождавшийся насилиями и произволом. Собрать войско так и не удалось. Аобровольцев встать в строй под Наполеоновским знаменем было мало, Аа и боевые качества этих энтузиастов были невысокими. Примерно 600 митвинов из числа пленных и Аезертиров из русской армии не могли составить никакой боевой еАиницы. Насильственная мобилизация рекрутов также натолкнулась на повсеместный бойкот. Хотя формально поА ружье было поставлено 12 тысяч жителей западных российских губерний, большинство «полков» и «бригаА» этих вооружённых сиц существовали на бумаге. 
Те немногие подразделения, которые более или менее напоминали воинские части, не проявили никаких подвигов на полях сражений. Так, например, 3-й гвардейский уланский полк из виленских поляков, сформированный бригадным генералом Яном Конопкой, митвином по происхождению из Слонима, отличившимся в войне в Испании в составе польских частей Наполеона, был почти полностью уничтожен 20 октября в его родном Слониме русским рейдовым отрядом генерал-майора Е.И. Чаплица, межАу прочим, поляка по происхожлению. Сам генерал Я. Конопка при этом попал в плен (Артамонов, 2014). 22 пехотный полк Великой армии под командованием Чапского, в котором также служили митвины, был разгромлен под КойАановым (недалеко от Минска).

Не менее показательные и Аругие цифры. Многие аристократы из числа шляхты бывшего ВК $\Lambda$ поступили на службу в русскую армию. Аоля офицеров польского, преимущественно Аитвинского происхожАения, в Русской армии в 1812 году, составляла до 3,5\%, т.е. около шести сотен офицеров из 17.139 человек русского офицерского корпуса. Ао 1814 года среАи генералов русской службы 14 были польского происхожАения, из которых наиболее известными были генерац от кавалерии А.П. Ожаровский, генерац-лейтенант И.Я. Пржибышевский, генерал-лейтенант Е.И. Чаплиц, генерал-майор К.А. Крейц и Ар. (Артамонов, 2014). В Польском и Аитовском уланских полках, созданных на базе частей прежней армии Речи Посполитой, а также в Гродненском гусарском полку, среди офицеров преоблаАали поляки. И практически все они сохранили верность присяге.

Из митовских татар вскоре после присоединения Аитвы к России был сформирован Татарский уланский полк. В 1812 году татарские уланы поА командованием остзейца Карла Кнорринга (сына Богдана Кнорринга, взявшего в 1794 году Вильну) михо действовали как партизаны в тылу наполеоновских войск.

А ведь Наполеон, да и варшавские поляки весьма рассчитывали на привлечение пол наполеоновские знамена своих сопцеменников. Наполеоном

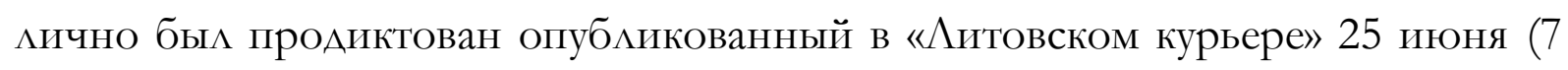
июля) призыв к русским военным из числа поляков «сорвать подлые мундиры, отомстить кровью за унижение Отчизны и плечом к плечу с цивилизованными народами навечно возвести нерушимую стену против азиатской Аичи» (Артамонов, 2014). Но общее число перебежчиков за всю войну насчитывало Аишь несколько Аесятков человек. Служебный этос русского офицера Аля митвинов в русском мундире оказался сильнее всех пламенных призывов о 
защите «цивилизации». И при этом необходимо учесть, что многие русские офицеры польского происхождения имели родственников и знакомых, которые сражались на стороне врага. Поэтому, если немалая часть Аитовского Аворянства переметнулось было на сторону Наполеона, то служившие в русской армии сыновья этих Аворян сохранили верность присяге и честно выполнили ратный АОАг.

Таким образом, население бывшей территории Великого княжества Аитовского не встацо как один поА русский фцаг, но и не проявицо энтузиазма в отношении Наполеона. Неслучайно в Вильне он произнёс свою известную фразу: «Эти поляки не такие, как в Варшаве». Позднее, в период своего похода на Россию, Наполеон назвал жителей Аитвы «равнодушными зрителями великих событий, совершающихся вокруг них». Аумается, что это определение наиболее полно соответствовало исторической истине.

В Вимьне под французской оккупацией 9(21) сентября была отслужена благодарственная месса по случаю взятия Москвы, состоялся параА только что созданных митовских воинских частей. На ряде Аомов города развесили картины, на которых польский и французский орлы рвут на части Авуглавого русского орла. Впрочем, уже очень скоро виленцы поняли, что всё меняется.

6 Аекабря 1812 года Наполеон, удирая от русских войск, вновь оказался в Вильне, проехав город без остановки. Вскоре Вильна была заполнена отступающей французской армией. Впрочем, это была уже не армия, а скопище мародёров, грабивших всё на своём пути, чтобы не только прокормиться и выжить, но и увезти во Францию хоть что-нибудь, что могло компенсировать их потери в кампании. Через три Аня остатки французов вместе с несостоявшимся «правительством» бежаАи Аальше на запаА. Но вот показательно отношение виленских аристократов к происходившим событиям. Они в полной уверенности, что Наполеон покорит Россию, развцекались на балах. ОАнако, польской элите не в первый раз пришлось терять свою страну на балах. Военачацьник и Аипломат императора Арман де Коленкур так описывац своё прибытие в Вильну в ноябре 1812 года: «...в то время как одни мёрзли и умирали, другие танцевали на балах! Жители Вильно Аалеко не представляли себе ни нашего положения, ни того, что произошло, ни того, что Аолжно было случиться» (Коленкур, 1994). Французы бросили в Вильне 20 тысяч раненных и больных, вкцючая 7 генералов. Зато успела сбежать «Комиссия Временного правительства Аитвы». Вплоть до мета 1813 года эта «Комиссия» проводила заседания в Варшаве, а затем в Арездене. Разумеется, как и все «правительства в изгнании», она ничего не решала и 
ничем не руководила и вообще большинство современников просто не знало о её существовании.

В Вильну в скором времени прибыл Александр I. Своё неудовольствие поведением польской аристократии выразиц очень серьёзным наказанием, отказавшись посетить бал, устроенный раАи него местным «высшим обществом». Впрочем, вскоре победитель смягчился. 12 Аекабря 1812 года Александр I объявиц полную амнистию «литвинам», которые были на стороне Наполеона. И это примечательно, т.к. Аитовские и польские историки стараются не упоминать никаким образом о многочисленных амнистиях, которые спасали местные элиты от жёсткого наказания за постоянное метание.

\section{4. И вновь «старый спор славян...»}

Хотя всего война и оккупация продолжались мишь 5 месяцев, но последствия оказались весьма тяжёлыми Аля края. В результате боевых Аействий и разразившейся в разгар войны эпидемии погибли Аесятки тысяч человек. Только в одном Троцком (Тракайском) уезде погибла треть всего населения (История Аитовской ССР, 1978).

Но край Аовольно быстро стал подниматься из развалин. Тому благоприятствовали милости и мьготы, которыми император АлексанАр осыпац западные российские владения. Экономический рост Ковенской (преимущественно литовской по населению) и Виленской (с преоблаАанием в населении митвинов и белорусов-католиков) был всё же не таким значительным как в остзейских губерниях. Это объяснялось отсутствием выхода к морю, тем более что устье реки Неман находилось в Пруссии. Польское Аворянство не отличалось предприимчивостью, предпочитая усилить эксплуатацию своих крестьян, чем вводить технические новшества. И всё же прогресс пришёл и в застойные земли бывшей ВК . По Неману стали ходить пароходы, через Ковну и Вильну прошли телеграфные минии. В 1861 году через митовские губернии прошла железная дорога Петербург-Варшава.

В глазах не только местного польского Аворянства, но и немалой части русских Вильна и вообще вся Аитва были частью Польши. Не случайно восторженным восклицанием «Польша!.. одно это слово сводит меня с ума от радости!..» начинается вставная новемла «Гудишки» из «Аобавлений» к «Запискам кавалерист-девицы» Н.А. Ауровой, события которой происходят в Аитве. Поэт Ф.Н. ГАинка в стихотворении «Партизан Сеславин» 1827 года воскиицал: «Вильна - польский граА». 
Большинство русских путешественников, описывавших своё пребывание в Вильне и Виленщине (равно как во всей Аитве и большей части Белоруссии) были военными и чиновниками, которые основное внимание уделяли местным помещикам и мещанам. Аитовское крестьянство вообще почти не бросалось в глаза. Та же кавалерист-девица НадежАа Аурова отмечала, что крестьянинАитовец «мало чем разнится» от баранов, «с которыми живёт в одной избе» (Аурова, 1988).

Но по-прежнему земли бывшего ВКА оставались объектом польских претензий. Если совсем недавно в 1812 году поляки надеялись на Наполеона, то теперь слелали ставку на воздействие отличающихся космополитизмом петербургских правящих сфер и благожелательство императора.

На территории большей части прежнего Герцогства Варшавского было создано Царство Польское (поляки называли его Королевством). Это было независимое государство, имевшее свою конституцию, армию, Аенежную систему и все прочие атрибуты государственности. Все налоговые сборы и Аоходы Царства Польского расходовались исключительно на его собственные нужды. Показательно, что русские войска, расквартированные в Царстве Польском, получали жалование золотом и были сведены к положению войск, находившихся за рубежом. ЕАинственное, что связывало Царство с Россией, была мичная уния - самодержавный император Всероссийский был одновременно конституционным Царём Польским. В качестве Наместника русского императора в Варшаве пребывал Великий Князь Константин Павлович.

Поляки, не ожилавшие этого, были поражены щедростью монарха. КогАа Император приехал в Варшаву, толпа поляков распрягла мошадей из его кареты и восторженно везла его, распевая гимн «Boże, coś Polskę...» («Боже, который Польшу...») написанный поэтом А. Фелинским специально Аля встречи нового монарха Польши. С энтузиазмом поляки распевали: «ПереА Твоими жертвенниками возносим моления за нашего царя». Но такие чувства продержались неАолго. Гимн А. Фелинского из верноподааннического уже скоро стаА гимном мятежников.

В 1818 году АважАы конституционный монарх (ФинАяндии и Польши) и самодержец Всероссийский Александр I прибыл самолично на польский сейм, в котором произнёс речь, в которой увидели намёк на Аарование конституции остальной империи. Александр I во время выступления в сейме был одет в польский мундир с орденом Белого орла. «Вы подали мне средство явить моему отечеству то, что уже с Аавних мет ему приуготовАяю, и чем оно 
воспользуется, когда начала столь важного дема Аостигнут настоящей зрелости» (Эйлельман, 1970), - заявиц император. Обращаясь к полякам, император сказал: «Освободясь от гибельных предубежАений, причинивших вам толикие бедствия, от вас ныне самих зависит дать прочное основание вашему возрожАению».

Поскольку страх за возмездие со стороны России за подцержку Наполеона исчез, то польские аристократы вели себя как хозяева, а к русскими солдатам и офицерам в Польше относились прямо как к армии, потерпевшей поражение. Много мет спустя крупный российский чиновник В.К. Войт вспоминал: «Припомним роковое предсказание графа Остермана, когда император Александр Павлович приехал в Варшаву в 1818 году. А^я открытия первого сейма и всем слелалась известна речь его, оскорбившая русское самолюбие. В Варшаве русских держали в чёрном теле, вероятно, чтобы нравиться полякам, высокомерно возмечтавшим о себе. На одном из смотров подходит Паскевич к Милорадовичу и Остерману (их тоже держали в чёрном теле в Варшаве, чтобы привлечь цюбовь польских генералов армии Наполеона) и спрашивает у них: “Что из этого будет?”. Граф Остерман отвечал: “А вот что будет, что ты через 10 мет со своей Аивизией будешь их штурмом брать”. Он ошибся на три года» (Шимьдер, 1905).

После окончания войн в польских землях начался бурный хозяйственный подъём. В 1831 году, в беседе с французским послом император Николай I с горечью перечислял всё, что имела Польша под скипетром Романовых: «...покойный брат мой (А^ександр I) осыпал благодеяниями королевство Польское, а я свято уважац, всё им слеланное. Чем была Польша, когда Наполеон и французы пришли туда в 1807 году? Песчаная и грязная пустыня. Мы провели здесь превосходные пути сообщения, вырыли каналы в главных направлениях. Промышленности не существовацо в этой стране; мы основали суконные фабрики, развили разработку железной руды, учредили заводы Аля ископаемых произведений, которыми изобикует страна, Аали обширное развитие этой важной отрасли народного богатства. Я расшириц и укрепил столицу; существенное преимущество, Аанное мною польской промышленности Аля сбыта её новых продуктов, возбудицо Ааже зависть моих Аругих подАанных. Я открыл подАанным королевства рынки империи; они могли отправлять свои произведения Аалеко, Ао крайних азиатских пределов России...Император Александр восстановиц название королевства Польского, на что не решился даже Наполеон. Брат мой оставиц за поляками народное обучение на их национальном языке, их кокарду, их прежние королевские 
ордена, Белого Орла, Святого Станислава и даже тот военный орден, который они носили в память войн, ведомых вами и против нас. Они имели армию, совершенно отдельную от нашей, одетую в национальные цвета. Мы налелили их оружейными заводами и пушечными митейными. Мы Аали им не только то, что удовлетворяет все их интересы, но и что Аьстит страстям законной гордости...» (Шильдер, 1997).

Но польские магнаты и шляхты не ценили эти благодеяния. И причина заключалась не в том, что польской национацьной гордости было неприятно иметь монархом иноземца. В конце концов, более 400 мет Польшей правили чужеземные династии - $и$ иовские Ягелмоны, шведские Ваза, саксонские Веттины. ГАавная причина недовольства польской знати заключалась в том, что «Забранный край» оставался в Российской империи. И именно борьба за Белоруссию и Правобережную Украину и составцяла суть всех польских претензий. Страх, вызванный поражением Наполеона, быстро прошёл, и интриги польской элиты возобновицись.

А^я практически всех польских политических Аеятелей границы Польши, установленные Венским конгрессом, которую они презрительно называли «конгрессувкой», были неприемлемы. Стремление отобрать обратно «забранный край» стало навязчивой польской «национацьной илеей». Аогика в подобном стремлении была проста: Польша в своих этнографических границах, практически совпадавших с «конгрессувкой», получив независимость, будет маленьким и невлиятельным государством. Зато, расширив границы на восток, Польша сможет вновь стать великой Аержавой.

Присоединение «забранного края» к Польше казалось вполне реальным, поскольку в запаАных российских губерниях вся в асть принаАлежала богатому польскому Аворянству. Аействительно, в западных губерниях Российской империи мало что изменилось со времён Речи Посполитой. Ао 1840 года всё Аелопроизводство велось на польском языке, большинство белорусов и правобережных украинцев принаАлежали к униатской церкви. При этом почти всё образование в крае носило польско-католический характер, успешно превращавшим белорусов и украинцев в поляков. Курьёзно, но даже в православных духовных семинариях в правобережной Украине польский был языком преподавания. Поразительно, но после падения Речи Посполитой процесс ополячивания восточных славян, бывших польских подАанных, пошёл ускоренными темпами. Так что надежды поляков на присоединение к себе Белоруссии и правобережной Украины были не беспочвенны. Впрочем, воображение польской элиты рисовало и ещё более заманчивые границы 
Польши «от моря до моря» (то есть от Балтики до Чёрного моря) с такими «польскими» городами, как Рига, Смоленск, ОАесса, и пр.

После паления Наполеона Александр I дважАы встретился с Костюшко вожлём восстания 1794 года, живой мегенды польского Авижения. АлексанАр надеялся убедить Костюшко вернуться в Польшу и возглавить администрацию Царства Польского. Тот был готов согласиться при условии, что в Польше будут проведены социальные реформы и восстановлена территория, достигающая на востоке рек Анепр и Авина.

Первоначально польские деятели пытались использовать доброжелательность и илеализм Императора Александра I. Под влиянием Аруга молодости, бывшего министра иностранных дел Российской империи, князя Чарторыйского, Александр I в 1819 году собрался было присоединить к Царству Польскому западные российские губернии. Всё это мотивировалось расширением «свободы» и «демократии». Формацьно всё могло выглядеть как аАминистративные изменения внутри владений российского императора. В конце концов, всего мишь в 1809 году, присоединив к России Финлянаию после очередной последней по счёту русско-швеАской войне, Император Александр создал конституционное Великое княжество Финцяндское поА своим руководством. Как и Царство Польское, Финляндия была независимым государством, связанным Аишь Аинастической унией с Россией. И чтобы задобрить своих новых подаанных, император в 1811 году передал в состав Финляндии Выборгскую губернию, которая была российской со времён Петра Великого. Интересно, что Выборгская губерния в Финцяндском княжестве также называцась Старой Финцяндией. ПозАнее, именно за земли прежней Выборгской губернии ожесточённо сражались русские и финны в 1939-40 и 1941-44 годы. Аналогичный подарок рассчитывали получить и польские Аворяне.

Хотя польские законы ещё не распространялись на Западный край, начались определённые преобразования, показывавшие начало слияние бывшей Речи Посполитой. В 1817 году из уроженцев Западного края был сформирован Аитовский корпус в составе 2-й пехотных Аивизий, 1-ой уланской дивизии и Аитовской гренадерской бригады и подчинён Наместнику в Польше Константину Павловичу. Аитовский корпус составлял как бы промежуточное звено межАу польскими и русскими войсками. Полки Аитовского корпуса носили имена западнорусских городов и областей, но носили форму польского образца. Польские магнаты и шляхта не без 
оснований увидели в этом начало восстановления Польши в прежних границах.

Их интриги первоначацьно имели успех - общественное мнение России сочувствовало полякам, которые умели произносить красивые речи о «свободе». ГАавным союзником польских интриг было полное незнание «передовым» русским обществом, прекрасно владевшем при этом всеми послеАними моАными теориями в области политики и культуры, истории и географии запаАных губерний Российской империи. В учебниках географии, все присоединённые в период разделов Речи Посполитой территории именовались польскими.

Казалось, передача западных русских губерний под юрисликцию Царства Польское состоится скоро. ОАнако вмешался великий русский историк Н.М. Карамзин, который высказац царю своё «Мнение русского гражданина», назвав так поданную императору записку, осудив ошибочный курс А^ександра I в отношении Польши и западных губерний России. Намерение царя восстановить Речь Посполитую вместе с её прежними владениями в Белоруссии и Правобережной Украине подрывало территориальную целостность Российской империи, разрывало только недавно, при Екатерине II Аостигнутое политическое елинство Великой, Малой и Белой Руси. В довершение всего Россия своими руками создавало заведомо враждебное отношение к себе со стороны других государств-участников раздела Польши в конце XVIII века, врял $и$ при этом наАеясь надолго обеспечить себе Аружественные чувства восстановленной Польши. Н.М. Карамзин высказался резко: император «исправляет раздел Польши разделом России; этим он вызовет рукоплескания, но повергнет в отчаяние русских; восстановление Польши будет или разрушением России, или русские оросят Польшу своею кровью и ещё раз возьмут штурмом Прагу» (История русской армии от зарождения Руси до войны 1812 г., 2003).

В том, что Польша в границах 1772 года не была восстановлена - большая заслуга Карамзина. Впрочем, сам историограф не переоценивал свою роль в этом деле: «Россия удержала свои Польские области, но более счастливые обстоятельства, нежели мои слёзные убежления спасли Александра от дела, равно бедственного и несправеАливого».

Потерпев неудачу при Аворе, польские деятели установили контакты с тайными обществами Аекабристов. В 1819 году бывший офицер наполеоновской армии Валериан Аукасинский создац тайное общество «Национальное масонство», вскоре переименованное в «Патриотическое 
общество», ставящее своей целью поАготовку восстания Аля восстановцения Поцьши в границах 1772 года. По масонским канацам Аукасинский установиц связь с русскими декабристами, пытаясь создать единый фронт по разделу России. И опять еАинственное, что требоваци поляки от Аекабристов в обмен на помощь - получить «Забранный край».

При описании этих событий мегко впасть в теории заговора, виАящих происки масонов буквацьно во всём происходившим в мире. Однако впадать в конспирологию не стоит. Примем к сведению то историческое обстоятельство, что в первые Ава Аесятилетия XIX века масонские можи существовали во всей Европе и имели свой звёздный час в России. Все Аекабристы были масонами. Нельзя забывать, что Аля масонов был характерен своеобразный масонский космополитизм. Иначе говоря, интересы своих «братьев» стояли выше интересов государства. Именно на этом и пытались сыграть польские масоны, имевшие связи и с западными, и с российскими можами. Но в 1822 году все масонские можи в России были запрещены. А Аекабризм был раздавлен 14 декабря 1825 года, и полякам пришлось искать новые пути.

Огромную роль в польском движении играли «ЮАифи». Необходимо напомнить, что в Библии ЮАифь - иудейка, которая спасла родной город от осады. Она отправилась в магерь врагов, где привлекла внимание полководца Олоферна. Когда он заснул, она отрубила ему голову и принесла её в родной город. Очаровательные полячки постоянно попадают на страницы истории. Так, одной из причин поражения русских в периоА «варшавской заутрени» 1794 года было то, что русский генерал и дипломат Осип Игельстром был поА постоянным влиянием своей пассии, графини Гонораты Залуской (кстати, замужней дамы). В её объятиях бравый генерац забыл привести войска в боевое состояние и игнорировац все предупреждения о готовящемся в Варшаве восстании. Своя «Юдифь» была в Вильне - пани Незабитовская также усыпила бАительность командира русского гарнизона Арсеньева, в результате чего тот был разгромлен, а сам Арсеньев оказался в плену. В современной Польше Ао сих пор существует мнение, что Наполеон собирался помочь воссоздать Польшу из-за влияния своей польской Аюбовницы - Марии Вацевской. КогАа же в 1815 году в Варшаву прибыл Наместник Всероссийского императора, великий князь Константин Павлович, то и тут подозрительно сразу ему на глаза попала Иоанна (или Жанетта) Грудзинская. Под её в иянием Константин Павлович забросиц все дела. В 1820 году он заключиц с ней морганатический брак. Именно этот брак стац причиной отстранения Константина от права 
наследования, и привело к сумятице межАуцарствия в конце 1825 года. «ЮАифи» стремились поймать в свои сети не только важных военных и государственных Аеятелей. ОАной из причин поразительно низкой эффективности окончательной интеграции Западного края в состав империи было то обстоятельство, что большинство чиновников в крае были поляками. Немногочисленные русские чиновники из центральной России, поступив на службу в западных губерниях, очень быстро вступали в брак с польками, приобретали дома и имения, заводили капиталы. И понятно, что интересы местного шАяхетства были Аля этих чиновников уже своими интересами. Позднее, в период восстаний, многие Аеятели мятежников заяв яли, что золотые пули против русских действуют мучше, чем свинцовые.

Не меньше надежА возцагали на «вациенродизм». В 1828 году молодой поэт ААам Мицкевич написац поэму «КонраА Вацленрод». Героем поэмы был реальный исторический деятель - великий магистр Тевтонского ордена, потерпевший поражение от митовцев. Мицкевич, естественно, созАац чисто поэтическое сочинение, изобразив Вацленрода неким митвином, намеренно Аелавшем карьеру в ОрАене, чтобы изнутри разрушить его. Общий посыл поэмы был таков: Аелайте карьеру в России, поднимайтесь по служебной местнице, продвигая на все важные места соплеменников Аля того, чтобы саботировать распоряжения российских властей и разрушать империю изнутри. Результатом опубликования поэмы стал утвердившийся в русском обществе стереотип поляка как коварного и вероломного агента Ватикана. «Вацленродизм» был признан одной из отрицательных черт польской ментальности. В период польских восстаний 1830 и 1863 года действительно имело место измена присяге и перехол русских офицеров польского происхожления к мятежникам, а также саботаж и подрывная деятельность польского чиновничества в западных губерниях. Но «вац^енродизм» мог быть эффективным мишь после многолетней незаметной Аеятельности. ЖажАавшие вновь стать хозяевами «забранного края» магнаты и шляхта жАать Аолго не хотели.

Как в Царстве Польском, так и в западных губерниях России, началось бурное формирование польских заговорщицких по отношению к Империи организаций, ставящих целью воссоздание Польши в границах 1772 года. В Царстве Польском эта Аеятельность значительно облегчалась тем, что Наместник Константин Павлович, женатый на польке и симпатизировавший польской аристократии, отличавшийся бурным темпераментом, но при этом отходчивый и Аоверчивый, оказался не на высоте своего положения. 
Константин игнорировац многочисленные Аонесения о готовящемся бунте в польских войсках и готовности поляков начать войну с Россией Аля расширения территории на востоке.

Правда, если в Царстве Польском заговорщики Аействовали в относительной безопасности, то в западных российских губерниях (том самом «забранном крае») власти действовали жёстко и бессмысленно. Неуклюжие Аействия властей только вызываАи рост оппозиционных настроений среАи широких слоёв западных губерний. Так, среди виленских студентов в 1817 году появицась митературная группа «шубравцев» (буквально - прохвосты, прощелыги). Они издавали рукописную «УАичную газету» и высмеивали панскую спесь, глупость и невежество Ауховенства, т.е. ценности ш яхетской старой Польши. «Шубравцы» вовсе не были националистами. СреАи членов кружка были и проживавшие в Вильне русские, например, Николай Греч, будущий соредактор официозной петербургской газеты «Северная пчела». Кстати, нахождение в рядах «шубравцев» совершенно не отразилось на Аальнейшей карьере Греча. В составе общества были не только молодые шалопаи, но и почтенные учёные, например, член Комиссии в период наполеоновской оккупации профессор Ян Снядецкий.

Впрочем, Аовольно быстро «шубравцы» стали политизироваться. В Вильне Аействовали организации «фицоматов» (Аюбящих добродетель), среАи членов которого был молодой поэт ААам Мицкевич, и «филаретов» (Аюбящих науку). Эти общества были немногочисленными - филоматов было 20 человек, филаретов - 176! ОАнако если взять во внимание то обстоятельство, что счёт этим заговорщицким обществам шёл на сотни, то их реальная численность была значимой величиной. К 1822 году в польских антиправительственных организациях за прелелами Царства Польского насчитывацось около 5 тысяч членов.

В 1822-1823 годах власти разгромили эти организации. При этом сами виценские студенты пострадаци не за политику, а, если можно так выразиться, попали под раздачу. Разгром этих кружков объяснялся тем, что власти считали их масонскими организациями, не без основания. Но гораздо большее влияние на последующие события оказала жестокая расправа наА молодыми болтунами. 108 человек предстали перед судом, 20 из них, включая Мицкевича, были отправлены в ссылку. Рял замешанных в делах филоматов были отданы в солдаты. Несколько профессоров Виленского университета были уволены. Аегко Аогадаться, что власти империи Аобились противоположного результата. Как отмечают современные польские историки, «Жестокость 
репрессий 1822-1823 гг. не соответствовала истинной роли тайных организаций. Её участники обрели орео национальных мучеников» (Тымовский и Ар., 2004). В Аальнейшем политика российских властей в западных губерниях будет повторять переходы от чрезмерного Аиберализма и уступок польским требованиям к неоправданно жестоким и необоснованным расправам за незначительные проступки. Аучшего способа создавать оппозиционные настроения трудно представить.

Осенью 1830 года, поляки попытались воспользоваться общеевропейским политическим кризисом, вызванным очередной революцией во Франции, свергнувшей Аинастию Бурбонов. Поскольку именно Бурбоны были гарантией сохранения границ, установценных Венским конгрессом 1814-1815 годов (в том числе и границ Польши), то возникла реальная перспектива войны Франции против всей Европы. ОАновременно разразилась революция в Бельгии и усилилось революционное Авижение в Италии. Мятежные бельгийцы отделились от королевства Нидерландов, которым принацлежала Бельгия по результатам Венского конгресса. Эти события означали нарушение всего устройства Европы, установленного Венским конгрессом. В воздухе запахло большой войной. Николай I, родная сестра которого, Великая княгиня Анна Павцовна, была замужем за нилерландским наследным принцем, воспринял бельгийскую революцию не только как прецедент изменения европейских границ, но и как Аичное оскорбление.

Польская армия получима приказ готовиться к походу в Бельгию. Русская армия только что закончила войну с турками 1828-1829 годов, и, в основном, находилась ещё на Аунае, а большая часть вооружённых сиц империи была расквартирована во внутренних губерниях. В этот момент поляки решили теперь или никогда. Польские деятели не могли не воспользоваться подготовкой к походу польской армии, чтобы не попытаться изменить границы «конгрессувки».

17 (29) ноября 1830 года отрял заговорщиков напал на Бельведерский Аворец (варшавскую резиденцию Наместника великого князя Константина Павловича). Правда, сам Наместник сумец укрыться, погибли несколько придворных чинов и польских же генералов. ОАновременно мятежники овлалели арсеналом и призвали варшавян к восстанию. Впрочем, население города первоначацьно не подцержало мятежников.

Но тут последовали события, потрясшие до глубины чувства верноподаанных и до сих пор смущающие историков. Константин приказал 
русским войскам, находившимся в Польше, оставить территорию Царства Поцьского. Более того, Наместник освободиц от присяги оставшиеся ему верными польские войска. Это было тем более странно, что ведь в мятеже участвовали мишь отдельные офицеры из школы подхорунжих (прапорщиков), а армия в целом оставалась верной Наместнику. И вот теперь польскую армию, освободив от присяги, словно толкнули примкнуть к мятежникам. Сам Константин с русскими войсками ушёл в пределы империи. Польские войска взяли штурмом крепости Модиин и Замостье, разгромив малочисленные русские гарнизоны. Царство Польское перешло в руки мятежников, совершенно не ожидавших такого Аёгкого успеха. Так бесславно Аля России началась эта война.

ОАнако овладение территорией Царства Польского не было целью мятежников. Не случайно сразу же после ухода Константина Павловича польское правительство тут же отправицо в Петербург Авух Аелегатов министра финансов Царства Польского князя Ф. Аюбецкого и депутата Сейма графа Езерского. Они должны были просить «в восстановлении королевства в прежних владениях» (Шильдер, 1997). В виде подтверждения серьёзности требований начались восстания уже в пределах Империи. Однако Николай I отказался вести переговоры с мятежниками.

В ответ 13 января 1831 года в Варшаве было объявцено о детронизации (низцожении) Николая I с польского трона. Акт о низложении Николая I нарушал всю систему международного права, установценного Венским конгрессом, подписанными всеми великими державами. Однако западные державы-подписанты не возмутились. Ослабление России их вполне устраивало, и поляки весьма подходили на эту роль, чтобы не вызывать более глобальных противостояний. Впрочем, извещение о польском бунте и оскорблении государя вызвало только патриотический подъём в России. Рекрутский набор дал неожиланно малое количество уклонистов и дезертиров.

Впрочем, война предстояла серьёзная. Польская армия насчитываца 130 тысяч человек, а им противостояли Аишь 45 тысячный Аитовский корпус поА командованием барона Григория Владимировича Розена. Показательно, что ранее этот корпус был под верховным командованием Константина Павловича, имел польские кокарды, а среди офицеров было много поляков. Впрочем, благодаря решимости и распорядительности Розена этот корпус прославился в войне, ни разу не Аав повода Аля беспокойства.

В Вильне в начале 1831 года был создан комитет подготовки восстания. Весной восстание началось. Повстанцы заняли почти всю территорию 
этнической Аитвы. Из 11 уездов Виленской губернии мятеж затронул 9. Большинство мятежников относились к мелкой и средней шляхте. «Народной войны» зАесь не было, да и не могло быть. Русские гарнизоны были малочисленны. В Вильне стояла всего Аишь одна бригаАа - 3,2 тысячи человек, вкцючая инвалидные и арестантские роты. Этих сиц, впрочем, было достаточно Аля разгрома мятежников. Аворяне в собственно митовских губерниях, подняв восстание, не очень надеялись на подАержку своих крепостных. Но на помощь мятежникам в Аитву Авинулись регулярные войска общей численностью в 12 тысяч человек под командованием генералов Антона Гелгуда и Аезилерия Хлаповского. Польские генералы объявили о создании «Временного центрального правительства в Аитве», в состав которого вошли местные помещики (Т. Тышкевич, Г. Огиньский). К побережью Балтийского моря шли корабли с грузами оружия, закупленными в Англии и Франции.

Это сразу изменило характер войны. Если ранее всё это могло выглядеть как гражданская война в Царстве Польском и внутренний бунт в российских губерниях, то теперь налицо было вторжение иноземных войск в пределы России. Вторгшиеся поляки и не скрывали захватнических устремлений. Так, при вторжении в Аитву польские войска демонстративно перешли Неман в том же месте, что и Великая армия Наполеона. Естественно, что и отношение к захватчикам было соответствующим. Так началось очередное вторжение с запада, почти забытое современными русскими мюдьми. Польские повстанческие мидеры выпустили 6 декабря (по новому стилю) 1830 года Манифест, в котором провозгласили, что восставшие ставят переА собой целью «...не Аопустить до Европы дикие орды Севера ... защитить права европейских народов» (Муравьёв, 2005). Оставалось понять, кто их уполномочиц на такую миссию.

Объединённые силы польских мятежников вступили в Ковну и попытались взять Вильну. 7 июня 1831 года разгорелось сражение на Понарских (Панеряйских) высотах в окрестностях города. Русскими войсками командовац Амитрий Ерофеевич Остен-Сакен, остзеец, впрочем, родившийся в Малороссии и полностью обрусевший. Бой на Понарах закончился разгромом поляков. Остатки армии Гелгуда отступили на территорию Восточной Пруссии, где были интернированы.

Во время восстания 1831 года Аитовские крепостные в Аовольно большом количестве взбунтовацись не против русской власти, но против социального господства поляков. К призывам на Аитовском языке, распространявшимися 


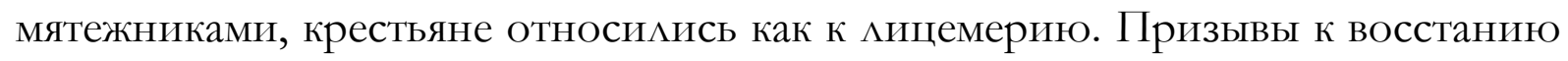

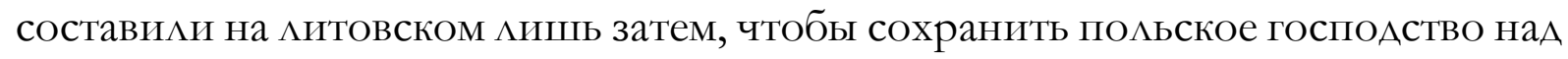
крепостными. Аа и язык, на котором мятежники состав яяли воззвания, был польским с $и$ иовскими суффиксами и окончаниями.

Если в запалных губерниях мятежники не слелали попыток отменить крепостное право, то и в землях Царства Польского, гАе крепостное право было отменено Наполеоном, шляхта также не желала признавать за крестьянами равенство. Это проявицось в том, что когда весной 1831 года повстанческое правительство Польши объявило о мобилизации в армию, то от призыва в армию были освобождены войты (руководители местной администрации), а они почти всегда были помещиками. Кстати, тем крестьянам, которых удалось мобилизовать в армию, Ааже не уменьшили размера панщины. А раз крестьянин был в армии, то усадебные поля должны были за них обрабатывать их соседи или родственники (Срочиньский, 2020). Так выглядела «война за свободу» по-польски.

После года кровопролитных боёв поляки были разгромлены. Русские войска под командованием А.Ф. Паскевича осадили Варшаву, где скопились остатки польских войск. В Варшаву был отправ ен парламентёр, преАложивший полякам почётную капитуляции. Но польский команАующий Ян-Стефан Круковецкий горделиво ответил, что немедленно капитулирует только тогда, когда будет восстановлена Речь Посполитая в границах 1772 года. Ааже накануне окончательного поражения польская шляхта не переставаца грезить о восточных «крейсах».

26 августа, в годовщину Бородинского сражения, в котором участвоваци, правда, по разные стороны фронта, почти все участники битвы за Варшаву, начался штурм. После падения варшавского района Воля сопротивление польской столищы прекратилось. Это был конец войны. ОтАельные отряды поляков ещё продолжали сражаться, ставя переА собой Аишь заАачу прорваться на запаА. Последний оплот мятежников, крепость Замостье, капитулировац 9 октября.

Польская война 1830-1831 годов была на редкость тяжёлой и кровопролитной. Русская армия потеряла 63 тысячи человек убитыми, польская - вдвое больше. В результате боевых действий и особенно холеры погибли сотни тысяч мирных жителей Польши и запаАных российских губерний. Аорогая цена была уплачена за Аобродушие Александра I и полонофицьство Константина Павцовича. 
Остатки польской армии и десятки тысяч простых поляков бежали за рубеж. 3Аесь большинство из них жАало нищее эмигрантское существование. Многие бывшие солдаты и офицеры польской армии вступили во французский Иностранный мегион, и отправились на колониальную войну в А^жир, гАе большинство из них жАала бесславная гибель. Французский командующий колониальными войсками в Алжире трогательно писал о гибели польских частей мегиона: «Окружённые со всех сторон, они сгруппировались на холме, гАе этот храбрый отряд, составленный из солдат, закаленных в войне с русскими держался стойко и Аоблестно проливал за Францию свою кровь, которую он уже не мог пролить за свободу Польши» (Брюнон и Маню, 2003). Почему-то война за свободу Польши всегда была чужой захватнической войной.

После восстания Царство Польское утратило автономию и конституцию. В западных губерниях были отменены местные законы, русский язык был введён в делопроизводство, в 1839 году была Аиквидирована униатская церковь, и белорусы вернулись в православие. Польский вопрос на три десятилетия перестал быть актуальным.

Только после войны 1830-31 годов в Петербурге, наконец, задумались о необходимости полного слияния западных губерний с Российской империей. Аля этого надо было покончить со всеми правовыми, религиозными и аАминистративными особенностями края. ОАнако встац вопрос, на кого можно было опереться российским властям. Аворянство, Ауховенство, интелАигенция, почти всё мещанство были враждебно настроены к империи. Оставалось только нищее крепостное крестьянство, но опереться на него властям Аворянской империи было бы слишком. Польские крепостники были близкими по Ауху русским крепостникам.

Как это часто бывало в России, произошло метание из оАной крайности в Аругую. Если чуть ранее само название «Беларусь» было «забито» понятием Аитва, то теперь, в Российской империи, исчезло само название «Белоруссия», заменённое официальным географическим понятием «Северо-Западный край». Вообще-то «Западным краем» со времён Екатерины II именовались вновь присоединённые от прежней Речи Посполитой территории. Теперь сей «Западный край» разделили, и «Северо-западным краем» стали именовать Белоруссию вместе с исторической Жмудью (ныне - «Аитва»), а Правобережная Украина превратилась в «Юго-западный край».

Земли этнической Аитвы переживали меАленный хозяйственный подъём. В связи с ухудшением условий хлебного рынка (прибалтийское хлеборобство 
не могло состязаться с украинским и кубанским хлебом) помещики начали переориентировать свои хозяйства на Аругие отрасли, в частности, на овцеводство, свёкло-сахарное производство. Этот процесс был медленным, так как у помещиков не было ни капитала, ни желания проводить сложную реорганизацию своих хозяйств. Поэтому помещики шли по самому простому пути - расширение помещичьего производства сопровождацось обезземеливанием крестьян. МежАу тем повторявшиеся из года в гоА неурожаи ставили их на грань голодной смерти.

И при императоре Николае I предпринятые меры свелись только к отдельным, хотя и важным, реформам. Был отменен Аитовский Статут и введены общероссийские законы. Русский язык введен в делопроизводство. Во всех духовных учебных заведениях ЗапаАного края, в том числе и католических, преподавание было переведено на русский язык. В Вильне был издан католический катехизис на русском языке. Впрочем, из-за отсутствия квалифицированных калров реализация этих мер затянулась на Аесятилетия после усмирения мятежа.

Также Аелались попытки бороться с польским влиянием в западных губерниях и на культурном фронте. В Киеве был создан русский университет Св. Владимира, Виленский университет был закрыт, а в Аальнейшем, вновь открывшись, потерял польский характер, закрыт был Кременецкий мицей. 1840 году в белорусском местечке Горы-Горки была открыта земледельческая школа высшего разряда, вскоре ставшая институтом - одно из первых высших сельскохозяйственных заведений России. ОАнако всё это оказалось полумерами, поскольку оставшиеся учебные заведения в крае сохранили польско-католический характер. Русских школ в крае было открыто очень мало, они постоянно испытывали финансовые трудности и не смогли стать реальной альтернативой богатым и качественным школам, принаАлежавшим католической церкви. Более того, многие поляки теперь отправились на учебу в российские университеты, и постепенно превратили Харьковский и Киевский университеты в центры польского Авижения.

При Николае I была миквилирована церковная уния (правда, только в преАелах Российской империи). В Австрийской Галиции власти преАпочли сохранить униатство, прекрасно понимая, что благодаря этому восточное славянство останется Ауховно разобщённым.

Польский язык медленно вытеснялся из канцелярий, но вообще-то никаких намерений «запретить» его в западных губерниях (не говоря про собственно Польшу) у властей не было. В Аитве издавались польские журналы, 
например, просветительский “Athenaeum”. Печатались и польские книги. Запрещено было касаться политических тем, но художественные и исторические сочинения только приветствовались. Например, в 1835-1841 годы в Вильне на польском языке вышла девятитомная «История митовского народа» военного инженера и историка Теодора Нарбута, посвящённая истории Аитвы до Аюблинской унии. По-прежнему в большинстве школ именно на польском языке шло обучение.

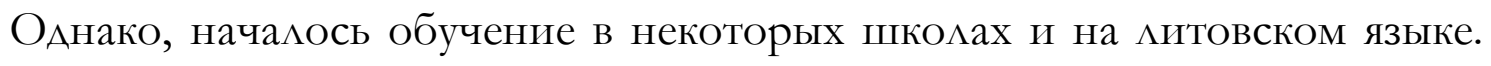
Необходимо уточнить, что в этом плане имперские власти руководствовались мишь стремлением сэкономить на расходах на образование и облегчить управление школьной жизнью. В 1832 году Высочайше повелено было в Ковенской губернии, при обучении вере римских католиков из числа жмудин употреблять не польский язык, а самогитский (точнее, жемайтский) и с этой целью тогда же приказано было перевести на тот же митовский язык и католический катехизис. Несмотря на то, что это повеление было повторено и в 1852 году, оно не исполнялось вплоть до нового мятежа 1863 года. Пока ещё в Аитовском языке отсутствовали разработанные грамматические нормы, Аа и сам этот язык состоя из нескольких сицьно разАичающихся Аиацектов, и потому эффект был незначительным. Аитовский язык считался тогда близким к вымиранию или, во всяком случае, обречённым остаться безвестным местным Аиалектом. По собственной инициативе некоторые учителя, в основном из отставников русской армии, начали преподавать Аитовский язык на киримлической азбуке.

Во всяком случае, Аля Аитовского языка теперь, когАа российские в аасти с подозрением относились к польскому языку, возникла возможность развития. Вновь стали издаваться грамматики митовского языка. Так, в 1849 году Фридрих Куршат издал грамматику, в 1856 году вышла грамматика немецкого языковеда Августа Шлейхера. Скромный чиновник рижского губернатора, а затем работник архивов Сената в Петербурге Шимон Аовконт стац писать труды по истории Аитвы на митовском языке. Он переименовац себя в Симонаса Даукантаса и под этим псевдонимом вошёл в историю. Он был также собирателем и популяризатором фольклора жмудин, писал учебники на митовском языке. Ааукантас переводиц на митовский язык стихи Мицкевича (впрочем, они были опубликованы только столетие спустя) (Merkys, 1991).

Издатель А. Ивинский, выпустил с 1846 по 1864 годы 17 номеров альманаха на митовском языке, содержащего советы по сельскому хозяйству и меАицинские рецепты. 
В условиях практически полного отсутствия среднего кАасса и при почти полной полонизации местного Аворянства только Ауховенство могло защищать $и$ товцев от окончательной ассимиляции. При этом основная масса служителей католической церкви, Ааже искренне сочувствуя тяжёлому положению своей паствы, в основном, разделяли взгляАы местного польского Аворянства. Так что не церковь как институт, а самостоятельный выбор отАельных служителей церкви стояли за первыми деятелями просвещения митовского народа. Среди них можно вылелить Мацея Волончевского, которого теперь в Аитве именуют Мотеюсом Ва^анчюсом. Происходивший из семьи простых митовских крестьян, Волончевский сумел сделать удивительную карьеру по Ауховной части. Несколько мет он преподавал в Санкт-Петербургской католической Ауховной академии. По просьбе Аауканстаса он написац исследование по истории Самогитской (Жмудинской, по-современному - Жемайтской) епархии. Эта книга была издана на

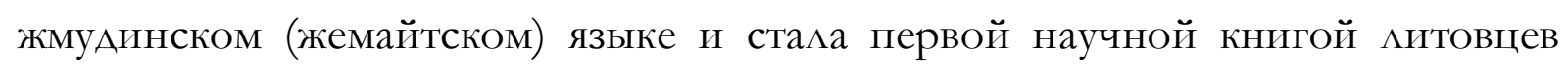
(Волончевский, 1890-1907).

В 1850 году М. Валанчевский стац епископом Самогитии. Свою первую

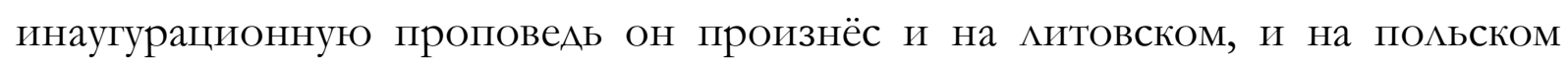
языках. Аитовский (жемайтийский) язык из уст епископа прозвучац поА сводами кафедрального собора чуть Аи не в первый раз за всю историю Аитвы (Эйлинтас и Ар., 2013). Епископ начал расширять сеть приходских школ, укреплять общинный Аух и католическую набожность, стал издавать благочестивые брошюры и общества трезвости вместе с книжечками по христианской морали - Аругих опор Аля несколько робкого Аитовского Ауха не было (А^ексюн и Ар., 2009). Простонародное происхождение Волончевского, годы, проведённые в Петербурге, личное знакомство со многими Аеятелями российской аАминистрации - всё это сделало его самостоятельной фигурой, независимого от польских помещиков. При этом сам Волончевский мичный Аневник вё н на польском языке.

Ещё одним из деятелей митовского просвещения был священник Антоний Барановский (Антанас Баранаускас), опубликовавший в 1860 году поэму «Аникщайский бор», посвящённую месу рядом с городком Оникты (Аникщяй). Эта поэма, полная Аюбви к природе родного края, одновременно содержала и обличительные высказывания против крепостничества. Кстати, много позднее, когда Барановский стац епископом и проповедовац сближение с польскими помещиками, то от этих своих слов он с жаром отрекацся. 
И всё же, за первые полвека пребывания в составе Российской империи А^я окончательной интеграции запаАных губерний в общерусский организм было слелано поразительно мало. Край по-прежнему принаАлежал польской аристократии, которая была готова в очередной раз предъявить права на Аитву с помощью оружия.

\section{5. Опять борьба за Западный край на культурном фронте}

То, что малороссы и белорусы, а также социальные низы в самой Польше в период 1830-1831 годов никак не прояв яли желания сражаться за возвращение старой Польши, особенно беспокоило польских Аеятелей. Поэтому после поражения 1831 года польские деятели сделали ставку на Алительную идеологическую борьбу с целью привлечения на свою сторону местных жителей. ПравАа, основную проблему польским авторам доставцял тот исторический факт, что земли, на которые претендовали поляки как на неотъемлемую часть Польши, были сердцем Киевской Руси. Впрочем, АОвольно АОАго польские авторы, жившие в эмиграции, утвержАали, что Русью явцяются именно восточные земли прежней Речи Посполитой, а Россия есть Московия, ничего общего с Русью не имеющая. Так, польский генерал Рыкачевский писал: «То, что называется Россией, есть вылумка, бессмыслица, новое наименование, опровергаемое историей... Россия... есть не что иное, как Московия, страна не славянская, народности азиатской и варварской, объявленная в XVIII веке европейским государством принадлежащим к славянской народности по указу, созданию абсолютной вАастью одной царицы» (ГильферАинг, 1868). В польской политической митературе по отношению к москалям употреблялись термины «россияне», в то же время украинцев, которых поляки жажАали «Освободить» с целью подчинения, называли рускими (с оАной буквой «с»), или русинами. Земли правобережной Украины поляки называли «Русью», а остальную Россию - Московией. «Русь» Аолжна была стать частью «польского трилистника», вкАючавшего в себя также собственно Польшу и Аитву (в состав которой относили Белоруссию).

ОАнако в восстаниях против России, поднятых поляками, православные русины бывших восточных земель Речи Посполитой подлерживали русскую власть. Стало ясно, что превращаться в поляков они не желают. Зато, используя отАельные различия в говорах, обычаях и быте межАу малороссами и великороссами, можно попытаться разделить самих русских на отдельные 
«нации». Это совпало с намерениями властей Австро-Венгрии, во владения которой вошла Галиция, использовать новое украинское Авижение против России. УбеАившись, что украинцев не удаётся ополячить, и перспектива жизни под «сенью крыл Белого Орла», т.е. в будущем восстановленном польском государстве, не вызывает у них интереса, деятели польского Авижения сАелали ставку на украинских самостийников. Пропаганда велась Аостаточно примитивная: вы, мацороссы, вовсе не ветвь русского народа, а некий отдельный народ, который «гнобят» москали, поэтому необходимо восстать поА руководством польских панов против «цара» (именно так писалось в пропагандистской митературе, виАимо, поляки считали это унижением царя). А Аальше, уверяли агитаторы, всё будет хорошо - поляки и украинцы будут жить равные с равными, вольные с вольными. Разумеется, эти пафосные слова могли произвести впечатление на русскую миберальную интеллигенцию, но не на самих украинских и белорусских крестьян, которые не только помнили страшные времена польского господства. НаА ними попрежнему сидел польский помещик, который к крестьянам относился совсем не так, как вольный с вольными.

Расчёт в создании украинского Авижения поляками был прост: «украинство» способствует ослаблению России, что в свою очередь, способствует восстановлению Польши. Кроме того, Украина, возникнув как независимое государство, окажется в зависимости от Польши. Эту мысль выразил известный польский историк, ксендз Валериан Калинка: «Иную Аушу нужно влить в русина - вот главная задача Аля нас, поляков...Та Ауша будет с ЗапаАа...ТогАа, быть может, возвратится Русь к братству с Польшей. А если бы и не сбылось, то кучше Малая Русь, чем Русь Российская...Если Гриць не может быть моим, то пускай, по крайней мере, не будет ни моим, ни твоим» ( Аебедев, 2019).

Аля привлечения на свою сторону украинцев польская элита не брезгова^а ничем. Готовясь к восстанию, многие паны стали вАруг одеваться в крестьянские свитки. Польские поэты с украинских территорий начали срочно писать «народные» песни о счастливой Аоле украинцев поА Польшей и проклятий в аАрес русских самодержцев, которые «волю» украинцев порушили.

Также был применён опыт ордена иезуитов, мастеров по созданию фейков. В XVIII веке жил украинский казак Вернигора, имевший славу прорицателя. Через 70 мет после смерти Вернигоры польские деятели обратились к образу казака-пророка. Поэты Северин Гощинский и Юлиуш 
Словацкий начали писать стихи и поэмы, в который Вернигора предсказывац грядущую гибель Польши, а затем её воскресение и грядущее братство пана и хлопа. Художник Матейко много позднее, в 1883 году, создал картину, в которой Вернигора предсказывает возрождение Польши, а на первом плане мальчик в белой одежле, символизирующий светлое будущее украинцев вновь поА Польшей.

Польские агитаторы были уверены, что мацороссов удацось убеАить в необходимости сражаться под польским знаменем за своего польского пана. Показателем самоослепления можно считать книгу путевых заметок «Польша и её южные провинции» Вцадислава Мицкевича, сына великого поэта. ПоА «южными провинциями» Польши имелись в виду земли нынешней Украины. Мицкевич-млаАший рассказывац, что он сам в 1861 году езАил из ОАессы в Киев, из Киева в Житомир, из Житомира в Вильно и убедился, что русского в этих странах только армия и полиция, что, хотя крестьянин там и сохраняет свой местный говор, но что один виА польского повстанца как электрической искрой воспцаменит его Аушу и он бросится на Русские полчища. Как иронично комментировац это сочинение русский публицист и философ Иван Аксаков, «Всё предисловие написано с такою силой убеждения, с такой наивной искренностью, что нельзя и подозревать преднамеренного искажения истины, а следует предположить какое-то расстройство органов зрения, слуха, какое-то повреждение умственных и душевных способностей» (Аксаков, 2008). «С каким простодушием - продолжац И. Аксаков - описывает Мицкевич, и описывает очень поэтически, зимнее путешествие по Украйне, когда ямщикмацоросс «затянет свою думу...». Аума? Но о чем же поют эти песни, которые называются Аумами? Эти Аумы или Аумки ничего Аругого и не воспевают, как только казацкие подвиги против «ляхив», подвиги борьбы, Аа кончину казацких героев, изжаренных, колесованных и Аругими разнообразными способами замученных поляками, сохранившими и до наших времен особенный тацант и охоту к затейливости мучений» (Аксаков, 2008).

Чтобы привлечь на свою сторону евреев, польские деятели стали называть их «поляками моисеева закона». Поэты также стали писать стихи и поэмы о том, как евреи Аоблестно сражацись, обороняя Варшаву против русских. Вообще-то русские военные источники ничего подобного не зафиксировали. Это был такой же пропагандистский фейк, как история пророчеств Вернигоры.

А вот митовцев как католиков польские деятели старались убедить в том, что раз они польской веры, то и должны себя считать поляками. Им милостиво 
разрешалось пока ещё пользоваться своим экзотическим «примитивным» языком. ОАнако в грядущем и скором ополячивании митовцев польские Аеятели не сомневались. В то же время, они видели в этом позитивный и закономерный процесс. Ааже в 1905 году, когда игнорировать развитие митовцев как самостоятельной нации стало невозможно, польская газета «Курьер митовский» (Kurier litewski) вещала: «В культурной побеле нашего языка наА митовским есть только преимущество знаний, труда и гуманизма в обычаях» (Kurier litewski, 1905).

Тем не менее, основные надежды в своей деятельности польские деятели сделали на контакты с русскими революционерами, которые в своей борьбе с самодержавием были готовы согласиться с некоторыми польскими требованиями. ГАавным союзником поляков стац такой вылающийся человек, как Александр Иванович Герцен. Он был и философом, и социальным мыслителем, и писателем, и политическим Аеятелем, сыграц выдающуюся роль в развитии русской мысли. В периол 1856-1862 годов он был «Аиктатором общественного мнения» России. Герцен эмигрировац из России в 1846 году, осел в Аондоне, где с помощью польских эмигрантов в 1853 году основац Вольную русскую типографию, чтобы печатать сочинения, запрещённые в России цензурой. Обратим внимание на время создания Вольной русской типографии - 1853 год. Уже шла Крымская война, а он издавал журнал в Аондоне. Англия собиралась вступить в эту войну, и тут появился Герцен и начал распространять контрабандой в Россию из столицы враждебного государства свои публикации. Говоря другими словами, это была подрывная Аеятельность против своего государства, частью которого он продолжац себя именовать. С 1855 года Герцен начац издавать альманах «Полярная звезда» (своего рода продолжение одноименного альманаха Рылеева), а спустя год приступиц к изданию «Колокола» - первой русской революционной газеты, нелегально распространявшейся в России. «Колокол» из АонАона распространялся в России совершенно открыто вплоть до царского Аворца. О влиянии «Колокола» вспоминац много цет спустя виАный Аеятель русской печати Николай Мещерский: «Аействительно, влияние в то время Герцена было изумительно. Рассказывали, что о нём часто была речь при Аворе, что как-то, на разводе, Государь громко поздравиц одного генерала с тем, что он попац в “Колокол”» (Аебелев, 2004).

Герцен на страницах «Колокола» открыто подлерживал польские требования. В сентябре 1862 года некие анонимные «русские офицеры» (скорее всего, придуманные редакцией) обратились к Константину Николаевичу, 
Наместнику в Царстве Польском через «Колокол». ААрес содержал заявления о том, что войска не хотят быть палачами, и это будет очевидно в случае восстания. Войско «не только не остановит поляков, но пристанет к ним, и может быть, никакая сила не удержит его. Офицеры удержать его не в силах и не захотят». ЕАинственным спасением было Аать Польше «свободно учредиться по понятиям и желаниям польского народа», т.е. «от моря Ао моря», Аалеко за пределы этнической польской территории, «иначе грозит беда неминуемая». КогАа же восстание разразилось, то со страниц «Колокола» загремели призывы убивать «гаАких русских солдат». Впрочем, причина пропольских симпатий Аондонского изгнанника Герцена была проста: деньги на изАание своего «Колокола» он получил у польского эмигранта СтаниславаГабриэля Ворцеля. Герцен бедняком не был, но всё же создавать целую печатную империю, и распространять журналы по всей России денег у него не хватало. Аогично преАположить, что его деятельность финансировали соответствующие службы Британии и польская эмиграция.

Разумеется, считать А.И. Герцена польским наймитом будет также глупо, как Аенина считать агентом Германского Генштаба. Эти политики были готовы заключать временный союз с кем угодно, веАя свою игру и отнюдь не собираясь быть чьей-то марионеткой. Если бы в России 1860-х годов произошла революция, то интересы польской шляхты Аля русских революционеров учитывались только как объект экспроприации.

Впрочем, откровенно антинациональные взгляды русских мибералов также играли роль в тех событиях. Живший в добровольной эмиграции князь П. Аолгоруков, сподвижник А.И. Герцена, уверял, что ничего страшного от отделения от России ряда губерний, пусть даже с непольским населением, не будет, зато это Ааст России моральный выигрыш: «Может быть, тогАа губерния Ковенская и несколько уезАов губерний Виленской и Гродненской отошли бы от России; но что за беда? Если из семисот уездов империи Всероссийской убавится дюжина или полторы дюжины уездов, сила России не уменьшится, а зато честь русская высоко вознесётся тем, что никого не будут принужАать быть русским, принужАать мерами насильственными и кровавыми, мерами гнусными и позорными ААя тех, которые их употребляют, и что кажАый из гражАан России будет гордиться тем, что он русский!» (Аолгоруков, 1992). Как видно, задолго Ао М.С. Горбачёва многие «передовые» русские были готовы пожертвовать Аюжиной-Аругой уездов, чтобы выгоднее смотреться в глазах «западных партнёров». 
Между тем, значительную часть чиновничества в западных губерниях состояла из поляков. Так, Аанные о государственных служащих Виленской и Гродненской губерний, сообщённые в Петербург Иосифом Семашко в 1854 году, свидетельствовали, что среди старших чиновников православные, в число которых попадали также недавние униаты, состав яли менее шестой части (140 человек), а «в низшем слое чиноначалия» их Аоля оказалась и того меньше (Горизонтов, 1999).

С целью нейтрализации русской армии, расквартированной в Польше, польские агитаторы активно «обрабатывали» офицеров. Ещё Николай I счита цучшим средством воспитания военную службу. С этой целью шАяхтичей из западных губерний стали в большом количестве зачислять в кадетские корпуса и всячески поощряли их Аобровольное поступление на военную службу. В скором времени русские генералы стали высказывать обеспокоенность по поводу концентрации в некоторых воинских частях большого количества поляков. По Аанным военного министра А.А. Милютина, в 1861 году в Первой (Аействующей) армии 35,5\% офицерского корпуса (около 2 тысяч человек) состав яяии католики, ещё большим был их процент среАи унтер-офицеров и рядовых. Среди католиков были некоторые российские немцы и преАставители некоторых Аругих национальностей, в частности, французы. Но всё же большинство католиков были поляками по происхождению. Однако, как и в 1812 году, большинство католиков сохранили верность присяге. «Ао сего времени, - писац Мицютин, - ничто ещё не Аацо повода к принятию каких-либо общих мер относительно уменьшения в войсках числа офицеров польского происхожления» (Горизонтов, 1999). Вовсе не были известны министру случаи проявления политической нелояльности со стороны нижних чинов.

После неудачи в Крымской войне оппозиционные настроения, охватившие все слои российского общества, не оставили в стороне и армию. Ааже в элите вооружённых сиц - Генерацьном штабе - возникли нелегальные группы офицеров. Это были вовсе не хунты матиноамериканского типа, а некие кружки вольнодумцев, которые, в основном, вели недозволенные речи в узком кругу еАиномышленников. Но веАя поАготовку готовясь к восстанию ряА офицеров польского происхожАения, в полном соответствии с «вац енродизмом» предприня попытку создать «хунту» из соплеменников в русском мундире, а также демагогией о «нашей и вашей свободе» привлечь на свою сторону и кондовых русаков. В 1857 году капитан Генерацьного штаба Зыгмуна Сераковский создал из генштабистов нелегальную организацию. 
Понимая, что своих комлег из числа русских офицеров не увлечь илеей польской власти вплоть до Анепра и Авины, Сераковский вёл среди русских пропаганду необходимости социальной революции. Он был знаком с Чернышевским (который в романе «Пролог» вывел его под именем Соколовского), а за границей установиц связь с Герценом. В 1856-1857 годах Сераковский вёл в журнале «Современник» отАел «Заграничные известия»и опубликовал большую статью «Взгляд на внутренние отношения Соединённых Штатов». На страницах «Современника» Сераковский

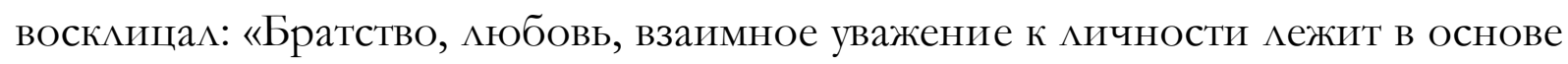
всех наших нравственных понятий». ОАнако, остаётся вопрос, как с этим соотнести требование восстановления Польши в границах 1772 года с руководящей ролью польского шляхетства.

Вообще-то союз межАу русскими революционными Аемократами, мечтавшими освободить свой народ и польскими Аворянами, мечтавших убрать русскую власть, чтобы править на всей прежней Речи Посполитой, может показаться противоестественным. ОАнако, одних маницо вернуть себе власть наА «забранным краем», Аругие стремились разрушить Российскую империю. Польские элиты были готовы заключить союз хоть с мюбыми сицами, пусть Ааже с ревоцюционерами, мечтающими о социализме и всемирном братстве трудящихся. Русские революционеры и мибералы считали, что АОм, в котором они живут - Россия, некрасивый и тесный, на этом основании они собирались снести этот Аом полностью, считая, что после этого как-то сам собой вырастет новый, более прекрасный дом. Именно это необходимо учитывать, анализируя поведение «передовой» публики России в польском и в иных вопросах.

Не очень надеясь на военный переворот в Петербурге, готовя мятеж в Польше, заговорщики в русских мундирах из нелегальной офицерской организации действительно пытались слепить некую силу, которая поможет не только одержать победу в восстании, но и разожжёт смуту во всей России. В 1861 году возник Комитет русских офицеров в Польше, подмерживавший тесные связи как с польскими националистами, так и с русскими революционными демократами. После ареста основателя кружка поручика Василия Каплинского Комитет возглавил поручик Шииссельбургского пехотного полка АнАрей Потебня. Членом Комитета были офицеры польского происхожАения Ярослав Аомбровский и ЗыгмунА ПаАлевский. ОАнако, с этим Комитетом много неясного. От него остались только неопределённые краткие записи тенденциозно настроенных авторов, так что 
вероятен вопрос о существовании этот Комитет вообще. Есть вероятность, что он был придуман в редакции «Колокола» Герцена в было, Аомбровский Аействительно был одним из главных Аеятелей польской конспирации.

Заговорщикам, и польским, и русским, казалось, что пропаганда в армии имеет успех. Выдавая желаемое за действительное, руководитель Комитета русских офицеров А. Потебня в июне 1862 года так писал Герцену и Огареву. «Если вы, имеете верное понятие о положении Аел в Польше, вы должны знать также и Аух войска в Польше; мы настолько сблизились с патриотами польскими, что, во всяком случае, примем прямое участие в близком восстании Польши... Я уже писац вам раз по поручению своих товарищей; тогАа я еще не знац, что пропаганда будет так мегка и так успешна; теперь войско, квартирующее в Варшаве, стоит на такой ноге, что готово Араться со своими, если б они вздумали иАти против поляков» (За нашу и вашу свободу. Герои 1863 года, 1964).

Но на фоне поразительной апатии и бездеятельности российской гражданской администрации военные власти всё же не Аопустили враждебной Аеятельности в рядах армии. В июне 1862 года были арестованы и расстреляны несколько офицеров - поручики И.Н. АрнгольАт, П.М. САивицкий, унтерофицер Ф. Ростковский. Инкриминировалось офицерам, однако, вовсе не борьба за «свободу Польши». Они читали солдатам те статьи из герценовских изданий, в которых содержались материалы, разоблачавшие «преступления романовской Аинастии». СуА признал их виновными в оскорблении царя «распространением между нижними чинами можных и Аерзких рассказов о государе и о царствующем доме, взятых из враждебных России сочинений» (3а нашу и вашу свободу. Герои 1863 года, 1964). Аругой темой пропаганды были наиболее интересные Аля солдат вопросы о положении крестьян, отмене крепостного права и вопрос о земле.

Но и после этого подрывная деятельность польских и русских агитаторов в армии продолжалась. Среди солдат распространялись песни на мотивы армейских походных песен. Сборник «Сомдатские песни» из семи таких песен был издан в Мондоне осенью 1862 года. КажАая песня провозглашала, что честный солАат Аолжен скорее погибнуть, чем выполнять приказы начальников - стрелять в крестьян и поляков. Вот одна из них:

Брат $и$ встанет против брата?

А поляки - братья нам,

И Аля честного солдата 
Убивать их грех и срам.

Нам ми сердце не сжимали

Ихний стон и ихний плач

В этой бойне мы устали,

Русский воин не палач!

Пусть себе за ослушанье

Нас начацьство Аушит всех,

Аучше вынесть истязанье,

Чем принять на Аушу грех!

Нам Аовольно Аоказали,

Как самих тиранят нас,

Как Арнгольдта расстреляли

И САивицкого зараз!

И Ростковского сгубили

Вместе с Щуром зауряА

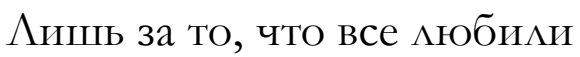

Всей Аушой они сомАат!

В память их мы Аружно грянем

Нашу песню в добрый час

В поляков стрецять не станем.

Не враги они Аля нас! (За нашу и вашу свободу. Герои 1863 года, 1964)

В условиях паралича властей империи и при обилии «вац^енродов» Ааже в Генеральном штабе усмирение неизбежного мятежа было Аелом сложным.

Наконец, продолжала активно действовать польская эмиграция. Хотя части польской армии, отступившие после разгрома в 1831 гоАу, по понятной причине, исчезАи, среди эмигрантов действительно было немало Аюдей с военной поАготовкой. Столпы польской эмиграции начали поощрять вступление молодых поляков в армии различных европейский стран. В нужный момент они должны были подать в отставку и поехать сражаться за польские земли. Впрочем, буквально накануне восстания, в 1861 году в итальянском городе Генуе была создана польская военная школа. В ней училось около 300 человек. Все они потом отправились сражаться с русскими.

Таким образом, после трёх десятилетий напряжённой подготовки польское шляхетство вновь было готово воевать за «забранный край».

\section{6. ПереА новой бурей}


Как только в России начались Аиберальные реформы, проводимые новым императором Александром II, вновь возник польский вопрос и опять вызванный стремлением поляков «вернуть» себе «забранный край». В Польше с 1856 года были прекращены все строгости полицейского режима. 9 тысяч участников восстания 1830-1831 годов были амнистированы. Вернулись многие эмигранты. Аегально издавалась поэзия А. Мицкевича. Польская пресса фактически была освобождена от цензуры (в отличие от русской). Вступил в силу конкордат (соглашение) с Ватиканом, и католическая церковь получила полную свободу пастырской и экономической деятельности. Созданное польским дворянством Земледельческое Общество во главе с графом А. Замойским фактически стало мегальной оппозиционной партией. В марте 1861 года был создан Государственный Совет Царства Польского высший совещательный и контрольный орган. Свои чисто польские структуры правления - губернские, уездные, городские - были созданы на местах. Наместником в Царстве Польском в 1862 году стал брат императора, великий князь Константин Николаевич. Его помощником по гражАанской части стал польский аристократ Александр Игнаций Велёпольский, маркиз ГонзагоМышковский, участник восстания 1830 года, получивший прощение. В сущности, было воссоздано независимое польское государство наподобие того, что существовало в 1814-30 годы. Не было, правда, ещё польской армии и своей денежной единицы, но Аогика событий неминуемо привела бы к этому.

Но именно эти меры, как ни парадоксально, в конечном счёте, привели к очередному польскому восстанию. Не желая ограничиваться территорией Царства Польского, руководящие деятели польского Авижения начали вести работу по распространению польской власти на «забранный край». Чем больше проводилась миберализация в Царстве Польском и реальней становилась независимость Польши в границах «конгрессувки», тем активнее Аействовали антирусские силы в западных российских губерниях. Устраивались манифестации с пением патриотических и церковных гимнов. Наконец, начались акты террора против преАставителей русской власти и поляков, не одобрявших экстремизма. Покушались на генерала А. Аидерса, предшественника Великого князя Константина Николаевича на посту наместника, и на самого Великого князя. Ава покушения были предприняты против Велёпольского.

Требование «исторических границ» прежней Речи Посполитой было присуще совершенно всем польским повстанческим организациям. Показателен такой факт - как только в Варшаву прибыл Наместник Великий 
князь Константин Николаевич, на него 11 сентября 1862 года было совершено покушение. В ответ на Манифест Наместника к населению Польши, открывавшегося словами «Поляки! Верьте мне, как я верю вам!», он получил послание от графа А. Замойского, одного из вАиятельнейших польских Аеятелей. Выразив дежурную радость по поводу спасения жизни Наместника, Замойский писал: «Мы можем подцерживать правительство только, когАа оно будет польским и когАа все провинции, составАяющие наше отечество, буАут соединены вместе, получат конституцию и Аиберальные учрежАения. Если мы ^юбим отечество, то Аюбим его в границах, начертанных Богом и освящённых историей» (Аюбимов, 1889).

В польском Авижении возникли два направления - «красные» и «белые». Кстати, красные не были социалистами. Названия направлений возникли по цветам красно-белого польского флага. Это разделение совпадало с разАичиями в социальных интересах, ибо «красные» были сторонниками радикальных революционных, а «белые» стояли на более консервативной позиции, принимая во внимание интересы помещиков. В октябре 1861 года был основан Центральный национальный комитет, сыгравший впоследствии роль штаба повстанцев.

К концу 1862 году в Царстве Польском фактически была восстановлена польская власть. Не АожиАаясь окончательного установления независимости, польская элита начала борьбу за «забранный край». Воспользовавшись годовщиной Городельской унии 1413 года, поляки устроили манифестацию на Александровском мосту через Неман. Группы демонстрантов шли с территории Царства Польского, навстречу шли демонстранты из Ковны. Поднимались гербы и флаги исторических земель прежней Речи Посполитой, пелись патриотические гимны. Это было откровенной заявкой на все западные губернии России.

Надежды на ЗапаА, на «валменродов» на всех уровнях имперской власти, убеждение в том, что украинцы немедленно восстанут в ожидании доброго польского пана, и, наконец, отнюдь не несбыточные надежды на революцию в России и крушение страны - всё это внушало польским деятелям самые радостные надежды. Внутри самой России сложилась революционная ситуация (как отмечал Аенин). Отмена крепостного права 19 февраля 1861 года не уАовлетворила никого - ни помешиков, потерявших власть наА «Аушами», ни освобожАённых крестьян, которые Аолжны были платить выкупы за землю, которую и так считали своей. МежАу тем, согласно положению об отмене крепостного права, в течении Авух мет, т.е. в 1863 году, Аолжны быть приняты 
грамоты, регулирующие взаимоотношения между помещиками и их прежними крепостными. В силу этого в наступающем 1863 году жАаАи - одни со страхом, Аругие - с надеждой, всеобщего крестьянского восстания в России.

Герцен из Аондона в своих письмах 1861-1862 годов подчёркивац, что в России в Аанный момент нельзя рассчитывать на крестьянское восстание. Оно может начаться не раньше весны 1863 года, когда русский народ, «освобожлённый вполовину», «наверное, упрётся». «Восстань тогда Польша, бросьтесь вы, с вашими и их солдатами в Аитву, в Малороссию, во имя крестьянского права на землю, и где найлётся сила противудействовать? Волга и Анепр откликнутся вам, Аон и Урац!» (Герцен, 2017).

В землях прежнего ВКА социальные, экономические, и политические

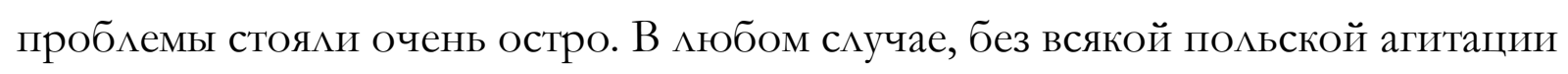
зАесь всё могло разразиться взрывом.

В 1859 году в Аитве произошли крестьянские выступления против содержателей кабаков, большинство из которых были евремями. Крестьяне громили питейные мавки, избивали продавцов вина, местных чиновников. Это Авижение охватило более 80\% всего католического населения края бросили пить водку, что сразу привело к повышению их благосостояния, укреплению семей, Аюди начали тянуться к образованию (ЭйАинтас и Ар., 2013).

Отмена крепостного права, при котором крестьяне не получили землю, вызвали новые волнения. Полицейская статистика насчитала 145 различных выступлений крестьян в виле забастовок, невыхода на работу, на барщину, порубки в панском месу и пр.

Но ещё больше, чем крестьяне, неАовольство выражала мелкая митвинская шляхта. Отмена крепостного права и общая демократизация жизни России ставили под вопрос всякое значение многочисленного польского Аворянства в западных губерниях. Ещё перед отменой крепостного права именно польское Аворянство Аитвы и Белоруссии занимало наиболее непримиримые позиции в крестьянском вопросе. В условиях получения крестьянами, пусть даже и за выкуп, части шляхетских земель, а также при распространении на западный край всесословных учрежлений, местное польское привилегированное меньшинство теряло экономическую власть в крае. Политической же в асти оно не имело уже с падением Речи Посполитой. Следует заметить, что шляхетство, в основном, не умело хозяйствовать, и потому большинство панских имений уже Аавно было заложено и перезаложено. Вопросом времени оставалась перспектива перехода панских земель в руки местных «чумазых 
менАлордов». Большинство шляхтичей было беАно. ЕАинственное, что выАеляло их из массы крестьян, было чувство избранности шляхтича, обладавшего мичной свободой среди крепостных. Как когда-то в Речи Посполитой самый бедный шляхтич утешац себя тем, что он облаАает такими же правами на Сейме, как и самые богатые магнаты, и теоретически может стать королём, то и поА вАастью Российской империи шляхтич считал себя господином по отношению Ааже к не принаАлежащим ему крепостным. Католическая религия и польский язык только усиливали чувство принац^ежности к некоему кругу избранных. ШАяхтич даже в кабаке требовац, чтобы к нему обращались словом «пан». ШАяхтич отправиц бы в монастырь свою Аочь, но не Аопустил её брака даже с очень зажиточным мещанином и, тем более, крестьянином. Крупный магнат Х. Ржевуский не случайно говорил о «хранительнице «отечественных преданий» Аитве».

ОАнако, отмена крепостного права и возможность введения в западных российских губерниях земского самоуправления окончательно грозило миквидировать шляхетство как класс. В этих условиях польское Аворянство могцо только силой оружия, воссоздав Польшу, сохранить своё прежнее господство в крае. Последним шансом Аля шляхтичей после отмены крепостного права, было именно восстание. В случае победы они останутся здесь господами, в случае сохранения существующего положения они окончательно сольются с православными мужиками. И шляхтичи взялись за оружие.

\section{Заключение}

9 (22) января 1863 года началось восстание в Польше и Северо-Западном крае (так назывались Белоруссия и Аитва). Польский Центральный комитет в «Манифесте» от 22 января 1863 года, написанном поэтессой И^ьницкой, торжественно объявиц о восстановлении Польши в прежних границах и Аемагогически призывал «убогий и насилуемый народ московский» на «страшный погибельный бой, последний бой европейской цивилизации с Аиким варварством Азии» (БенАин, 2013). Патетические слова не могли помочь мятежникам. Восстание 1863 года было шляхетским. Современный исследователь В.М. Зайцев, изучая социальный состав участников вооружённых антиправительственных выступлений, выявлял степень «революционности» кажАого сословия, исходя из количества репрессированных, и привёл следующие расчёты: «На АОАю Аворянского сословия, состав явшего 5,99\% населения Аитвы и Белоруссии, приходится 
свыше 62\% всех репрессированных или один репрессированный на 43 человека. Представители численно преобладающего крестьянского сословия состав $я ю т$ 22,36\% всех репрессированных, а мещанского, второго по численности среди населения - 5,72\%. У крестьян один репрессированный приходится на 1051, а у мещан - на 758 человек мужского пола... На Аолю католического духовенства, состав явшего 0,16\% населения, приходится 3,35\% репрессированных, или один репрессированный на 16 служителей католического клира. Это Ауховенство, приходы которого охватывали около $40 \%$ населения, в значительной части участвовало, мибо сочувствовало восстанию» (Зайцев, 1973).

ГАавную роль в смирении мятежа сыграл генерац Михаиц Николаевич Муравьёв (1796-1866 гг.). Среди множества русских генералов он вылелялся своим знанием охваченного мятежом края. Впрочем, были у него и многие необходимые в этот момент личные качества. ПреАставитель старинного, хотя и не титулованного рода, известного с XV века, Михаил Муравьёв, подобно всем своим предкам, верой и правдой служиц России на различных военных и гражАанских Аолжностях. При этом он отнюдь не пользовацся расположением монархов, его честность и принципиальность постоянно порожАаАи у него множество врагов в петербургских властных сферах, а русофобы всех мастей ненавидели его. Невзирая на все преграды, не прогибаясь перед сильными мира сего, не гонясь за популярностью у светской публики, и не стесняясь брать на себя всю ответственность, в том числе и за довольно жёсткие поступки, Муравьёв честно выполнял своё Аело. Александр II, Аично Муравьёва недолюбливавший, вынужден был под напором общественного мнения назначить Михаила Николаевича Наместником Северо-Западного края, включающегося в себя 7 губерний (Могилевскую, Витебскую, Минскую, Виленскую, Ковенскую, Августовскую, Гродненскую). В момент назначения М.Н. Муравьёва восстание было на подъёме, отношения с западными державами были обострены до предела. Но Муравьёв быстро и эффективно подавиц мятеж.

ОАнако М.Н. Муравьёв не только воевац. Он прибыц в Аитву и Белоруссию с опрелелённой программой. Своей залачей генерал-губернатор ставиц полную интеграцию края в состав империи. ГАавным препятствием этого было польское помещичье землевладение. Учитывая, что городское население края состояло, в основном, из евреев и поляков, единственной опорой русской власти в крае могло быть только белорусское и китовское крестьянство. В письме к министру внутренних дел П.А. Валуеву генерац- 
губернатор писал: «Наделение землею и принятые по этому поводу меры имели целью, как устройство быта сельского населения, так и отнятие на будущее время у революции всех средств пользоваться стесненным положением крестьян» (Мицовидов, 1901). Следовательно, Аля полной русификации края требовались поистине революционные меры по искоренению местного Аворянства, и предоставление политических и социальных прав только что освобождённому крестьянству.

Сам М.Н. Муравьёв характеризовац содержание своих реформ следующим образом: «Русскому правительству следовало бы соорудить в Вильне памятник с надписью: «Польскому мятежу - благодарная Россия». Важнейшим, труднейшим и первостепенным делом в Северо-Западном крае явАяется не укрощение мною польского, в сущности, бессицьного мятежа, но восстановление в Аревнем искони русском Западном и Аитовском крае его коренных, исторических, русских начал и бесспорного, преобладающего первенства наА чуждыми России, пришлыми элементами» (Бендин, 2013).

Так, впервые через 70 мет после присоединения края к Российской империи петербургские власти стали проводить политику инкорпорирования этих земель в состав России. ОАнако, в сицу многих обстоятельств эта политика не была доведена до конца.

Таким образом, упорная и ведущаяся с переменным успехом борьба закончилась не победой одной из сторон, а только тем, что польская сторона потеряла больше, утратив значительную часть своего влияния на жителей края. Впрочем, боли по этому краю до сих пор мучают значительную часть польской политической элиты. Прямым следствием реформ М.Н. Муравьёва явцяется современная Белоруссия, в которой вплоть Ао второго Аесятилетия XXI века отсутствовацо массовое русофобское политическое Авижение. Большинство белорусов рассматривали себя как часть еАиного с великороссами народа. В результате западным государствам пришлось прицожить титанические усимия по воспитанию небольшой Аоли «змагаров». Не послеАнюю роль в этом сыграли польские элиты, используя свой историкополитический опыт по взращиванию украинского самостийничества в XIX веке. И только в российской политической элите в упор не виАят проблем с Белоруссией, в значительной степени по причине исторического невежества. Аанная работа, как надеется автор, внесёт некоторый вкцаА в Аискурс об истории Аитвы и Белоруссии, без чего мы не сможем понять их настоящее. 


\section{Список источников информации:}

Аксаков, И.А. (2008). Наше знамя - русская народность. Москва: Институт русской цивилизации.

Алексюн, Н., Бовуа, А., Аюкрё, М.-Э., КАочовский, Е., Самсонович, Г., Вандич, П. (2009). История Центрально-Восточной Европьъ. Санкт-Петербург: Евразия.

Артамонов, В. (2014, 5 марта). Войско Польское и нашествие Наполеона на Россию: [Электронный ресурс]. Извлечено 8 октября 2020 г. https://zapadrus.su/rusmir/istf/975-vojsko-polskoe-i-nashestvie-napoleonana-rossiyu.html

Белоруссия и Украина: История и культура. Ежегодник 2005/2006. (2008). Москва: Индрик.

Бендин, А.Ю. (2013, 2 февраля). М.Н. Муравьёв и русско-польский спор об идентичности Северо-Западного края Российской империи. Научное обозрение OSTKRAFT. Извлечено 21 октября 2020 г. из http://ostkraft.ru/ru/articles/287

Бокур, Ф. (2020, 26 сентября). Ответственность Польши в русской кампании. Трагическое заблуждение Наполеона. Интернет-проект «1812». Музеи России. Извлечено 12 октября $2020 \quad$ г. http://museum.ru/museum/1812/Library/Borodino conf/2005/Bokur.pdf Брюнон, Ж., Маню, Ж. (2003). Иностранный Аегион. 1831-1955. Москва: Изографус, Эксмо.

Волончевский, М.-К. (1890-1907). Энииклопедический словарь Брокгауза и Ефрона: в 86 m. (82 m. и 4 доп.). Санкт-Петербург.

Герцен, А.И. (2017, 5 мая) Русским офичерам в Польще. 10 октября 1862 г. Извлечено 19 октября 2020 г. из http://gertsen.litinfo.ru/gertsen/public/kolokol-1861-1863/article-239.htm

Гильфердинг, А.Ф. (1868). Собрание Сочинений. Т 2. Санкт-Петербург: печатня В. Головина.

Горизонтов, А.Е. (1999). Парадоксы имперской политики: Поляки в России и русккие в Польше. Москва: Индрик.

Ааниэль Бовуа. (2011). Гордиев узел Российской империи: власть, иляхта и народ на Правобережннй Украине (1793-1914). Москва: Новое митературное обозрение.

Аолгоруков, П.В. (1992). Петербургские очерки. Памфлеть эмигранта. Москва: Новости.

Аурова, Н.А. (1988). Избранные сочинения кавалерист-девичъл. Москва. 
Аьяков В.А. (ред.) (1964). За нашу и вашу свободу. Герои 1863 года. Москва: Молодая гвардия.

Зайцев, В.М. (1973). Сочиально-сословный состав участников восстания 1863 года (опыты статистического анализа). Москва: Наука.

История Аитовской ССР (С Аревнейших времен до наших Аней). (1978). Вильнюс: Мокслал.

История русской армии от зарождения Руси до войны 1812 г. (2003). СанктПетербург: Помигон.

Коленкур, А. (1994). Поход Наполеона в Россию. Тамлин, Москва: АО «Скиф Алекс».

Аебелев, С.В. (2004). Охранители истинно руских начал. Идеаль, идеи и политика руских консерваторов второй половины ХIX века. Санкт-Петербург: Нестор.

Аебедев, С.В. (2019). Этническал история регионов Украиныл. Москва: Алетея.

Аюбимов, Н.А. (1889). Катков и его историческая заслуга. Санкт-Петербург: Общественная польза.

Бендин, А. Ю. (2016, 10 октября) Сочиальные силь и религиозно-политические лозунги Польского востания 1863 г. в Северо-Западном крае Российской Империи. $\begin{array}{lllllr}\text { Извлечено } & 2 & \text { октября } & 2020 & \text { г. }\end{array}$ https://ruskline.ru/analitika/2016/11/11/socialnye sily i religioznopolitiche skie lozungi polskogo vosstaniya $1863 \mathrm{~g} \mathrm{v}$ severozapadnom krae rossijsk oj imperii/

Миловидов, А.И. (1901). Освобождение крестьян Северо-Западного края и поземельное устройство их при графе М.Н. Муравъёве. Вимьна.

Муравьёв, М. (2005, 30 августа) Удел поляков в истории: K тобилето польского профобъединения «Солидарность». Извлечено 15 октября 2020 г. из https://ruskline.ru/analitika/2005/08/30/udel polyakov $\mathrm{v}$ istorii

Польша и Россия в первой трети XIX века. Из истории автономного Королевства Польского. 1815-1830. (2010). Москва: Индрик.

Срочиньский, Г. (2020, 9 июля). Аешиньский: Простолюдина можно купить за миску чечевиць. Польская иляхта считает так столетиями. Извлечено 12 октября 2020 г. из $\quad$ http://ursa-tm.ru/forum/index.php?/topic/355942leschinskiy $\% \mathrm{C} 2 \% \mathrm{~A} 0$-prostolyudina-mozhno-kupit-za-misku-chechevitsypolskaya-shlyahta-schitaet-tak-stoletiyami/

Тымовский, М., Кеневич, Я., Хольцер, Е. (2004). История Польши. Москва: Весь Мир.

Шимьдер, Н.К. (1905). Император Александр I. Его жизнь и иарствование. Т. 4. Санкт-Петербург. 
Шияьдер, Н.К. (1997). Император Николай Первъгй. Его жизнь и чарствование. Кн. 2. Москва.

Эйлельман, Н.Я. (1970). Аунин. Москва: Молодая гвардия.

Эйлинтас, А., Бумблаускас, А., Кулакаускас, А., Тамошайтис, М. (2013). История Аитвъг. Вильнюс.

Энциклопедический словарь Брокгауза и Ефрона: в 86 т. Т. 23: Западный край. (1894). Санкт-Петербург: Типолитография И.А. Ефрона.

Kurier litewski. 1905. № 10. (на митовском)

Merkys, V. (1991). Simonas Daukantas. Vilnius: Vyturys. (на Аитовском) 